\title{
The Investment Strategy and the Growth Policy of Greek Shipowners Revealed, 1946-2020
}

\author{
Alexandros M. Goulielmos'1,2 \\ ${ }^{1}$ Department of Maritime Studies, Faculty of Maritime and Industrial Studies, University of Piraeus, \\ Piraeus, Greece \\ ${ }^{2}$ Transport and Logistics Department, Business College of Athens, Athens, Greece \\ Email: ag@unipi.gr,am.goulielmos@hotmail.com, agoulielmos@bca.edu.gr
}

How to cite this paper: Goulielmos, A. M. (2020). The Investment Strategy and the Growth Policy of Greek Shipowners Revealed, 1946-2020. Modern Economy, 11, 1858-1886.

https://doi.org/10.4236/me.2020.1111125

Received: July 23, 2020

Accepted: November 21, 2020

Published: November 24, 2020

Copyright $\odot 2020$ by author(s) and Scientific Research Publishing Inc. This work is licensed under the Creative Commons Attribution International License (CC BY 4.0).

http://creativecommons.org/licenses/by/4.0/

\begin{abstract}
Greek shipowners do not believe in forecasting shipping markets, and are well aware of their cyclicality and volatility. We have showed elsewhere that shipping is a game with jokers, which appear suddenly and unexpectedly. After a long observation of the Greek owned shipping (GOS) strategy, we found-out that it builds and buys ships larger and newer, when a shipping cycle offers rock-bottom prices, and subsequently sells ships smaller and older. We showed this with data and with an adequate number of figures. We also found-out that technology has brought cycles faster in the markets! We have also showed the growth of GOS since 1856, and especially since 1945 . Greek ship-owners, with whatever cleverness they possess, they could not beat wars, recessions and depressions, as showed, but they tried to get advantage of them. Their timing was not perfect, but very good, as the prices at which bought $15682^{\text {nd }}$ hand ships were $86.5 \%$ cheaper (1983-1987) than in their peak price (1980). GOS pursues a cost leadership policy in all frontiers: economies of scale; economies of age; economies of low capital cost; low depreciation, and rock-bottom prices... Greeks proved that the 2009 crisis offered good opportunities, and they had the funds required.
\end{abstract}

\section{Keywords}

Greek-Owned Shipping Strategy, Fleet's Growth Since 1856 till 2020, Shipping Cycles, Long Waves, Impact of Technology on Cycles Frequency, Policy on Ships on Order, Acquisition Policy of $2^{\text {nd }}$ Hand Ships,

Theory of Perfect Timing in Ship Investments 


\section{Introduction}

One of the maritime 1750 analysts $^{1}$, who wrote a voluminous book (816 pages), Mr. Martin Stopford (2009: p. 94) argued that "shipping is unable to learn from its history"! He conceived shipping management as a "Poker Game" based on: Skill, Luck and Psychology! Goulielmos (2019), however, proved that shipping is a "Game with Jokers" in the packs. In post $2^{\text {nd }}$ WW period (1946-2020) 10 jokers appeared in the maritime pack (Goulielmos, op. cit.). COVID-19 is the last one.

Shipping, no doubt, cooperated all along with shipbuilding, mechanical engineering and naval architecture, and proved what efficiency/effectiveness really mean: i.e. ships continuously became larger-following economies of scale-with higher speeds, with port time reduced, and succeeded in keeping transport cost per ton, low, even, in a case recorded by Stopford, where 120 years $^{2}$ have elapsed!

Table 1 presents the estimated value of GOS among other 8 sea top global nations, 2019-2020.

As shown, COVID-19 reduced the value of the fleets of the 9 most powerful sea nations by $\$ 54$ billion (10\%) in just four months! This conclusion is drawn from the comparison of the value of the fleets in 2019 and in 2020 (April). It is supposed that this decadence in the value of the fleets was due to Pandemic in 2020 as nothing else so important has occurred.

Table 1. The value of the 9 top shipping industries worldwide, 2019-2020 (April).

\begin{tabular}{|c|c|c|c|c|c|}
\hline \multirow[t]{2}{*}{ Country } & \multicolumn{2}{|c|}{ Value 2019 , billion } & \multicolumn{2}{|c|}{ Value 2020 , billion } & \multirow[t]{2}{*}{ Remarks } \\
\hline & $\$$ (rounded) & $\%$ & $\$$ (rounded) & $\%$ & \\
\hline 1. Japan & 117 & 22 & 108 & 21 & Three \\
\hline 2. Greece & 102 & 19 & 100.5 & 20 & top global \\
\hline 3. China $\left({ }^{*}\right)$ & 100 & $19=60$ & 98.5 & $20=61$ & $\begin{array}{c}\text { Fleets }{ }^{*} \text { ) China is going } \\
\text { to surpass both Greece } \\
\text { and Japan... (estimate) } \\
\text { after COVID-19 }\end{array}$ \\
\hline 4. Singapore & 48 & 9 & 44 & 9 & \\
\hline 5. Norway & 46 & 8 & 39 & 8 & \\
\hline 6. USA & 39 & 7 & 33 & 7 & \\
\hline 7. Germany & 33 & 6 & 28 & 6 & \\
\hline 8. UK & 30 & 6 & 23 & 5 & \\
\hline 9. Denmark & 23.5 & 4 & 21 & 4 & \\
\hline Total & 538.5 & 100 & 495 & 100 & \\
\hline
\end{tabular}

Source: Vessels Value, April 2020.

${ }^{1}$ McConville \& Rickaby (1995), provided a shipping business \& maritime economics annotated international bibliography in which we have counted 1750 maritime economists worldwide between 1975 and 1995, and 131 maritime organizations.

${ }^{2}$ In 1871 , the cost of sea transport of 1 ton of coal from Wales to Singapore was $\$ 11.40$, and in 1990-2000 this was \$9.30, from UK to Singapore (roughly the same distance)! Source: Stopford (2009). 
Historically, Greece was a small country, mainly agricultural, as well mountainous, and poor; it had none of the prerequisites that other important sea powers, like e.g. UK, were endowed with. This led Adam Smith (1723-1790) to formulate, in 1776, his economic theory based on the endowed by nature resources, and division of labor, bypassing the knowledge-based industries, which need no resources, but brains and know-how.

In vain ancient Greeks showed what knowledge could achieve by organizing society so that slaves to carry-out manual labors, while masters were accumulating knowledge taking part in philosophical symposia! Today, it is a tragedy for Greece to "provide" brains to other nations through "brain drain", and the country to depend exclusively on Tourism and Shipping...

Greeks tell tales to their children, and their grandchildren, that Greece indeed has two "heavy-industries": Tourism (25\% of GDP) and Shipping! Tourism, however, hit badly by COVID-19, and to a lesser degree Shipping by locking away crews from their home for months. Greek tourism had certainly a substantial cut perhaps down to 5 or 6 million visitors estimated for 2020, from 33 million in 2018 and $18 \mathrm{~m}$ in 2008 ! Cruises had also contributed in the past with 5.5 million passengers...

Greece was occupied for almost 400 years $(1453-1829)^{3}$; it had a limited national trade $\left(\sim 33^{\text {rd }}\right.$ or so global position); a small own capital; no international banks, till 1960s; small shipyards, till 1970s; its fleet was made-up by old ${ }^{4} 2^{\text {nd }}$ hand ships for a rather long time; no coal, (but lignite), no oil, or iron-ore or gas... and no colonies to provide raw materials to Metropolis' factories.

Moreover, GOS paid its share to global freedom, during the 2 World Wars. A global war, though undesirable for its impact on human lives, and properties, in the end ${ }^{5}$ destroys the supply of ships, which is lost in hostilities. Moreover, it intensifies demand for sea transport for the endeavor of world's reconstruction.

One arrives naturally, as we did, we believe, at the question: "What on earth Greece possessed to become one of the first global shipping powers?” (Table 1). Greece is widely known mainly for its 3 S: Sun, Sand \& Sea... elements which established Tourism, but Greeks added an additional S (Sea), and an I (Islands), establishing... Shipping!

Moreover, GOS had people possessing maritime knowhow, who used to be merchants and shipowners at the same time, and seamen, and some of them (33\%) are today ex sea-officers (Captains and Engineers). Some call these factors Tradition ${ }^{6}$

${ }^{3}$ This acted, however, beneficially, as Greek merchants and shipowners departed from their country and went abroad... in free places and where their main antagonists, or trade, were, i.e. in London and Cardiff. No doubt they learned things from British shipowners, and surely built and bought ships there. They formed partnerships as well.

${ }^{4}$ In 1937 almost $62 \%$ of the GRT of Greek steamers aged greater than 20 years (Georgantopoulos, 1963: p. 9).

${ }^{5}$ Clever shipowners have their ships insured for war risks, and if ships are lost from war causes, they collect the insured amount mainly in $\mathfrak{E}$.

${ }^{6}$ Harlaftis (1996: p. 274), defined (shipping) tradition as that, (meaning rather the inherited knowhow), possessed by Greek shipowners, who belonged at least in a $2^{\text {nd }}$ generation after $2^{\text {nd }} W W$. We presume that traditional shipowners where in shipping business before $1^{\text {st }} \& 2^{\text {nd }} \mathrm{WW}$, i.e. since 1914. This means 3 plus generations till this day. We met shipowners with 5 generations in action. 
and Seamanship.

\section{Aim and Organization of Paper}

This is to explain: "How Greek-owned shipping _ GOS-reached-up and stayed on top of global positions"? For this we will pay special attention on GOS' "investment strategy", between 1945 and 2020. We believe that this strategy is mainly responsible for GOS' supremacy.

The paper is organized in 6 parts, after literature review: Part I, deals with the way tanker market functions, out of a series of selected figures, Parts II-V, deal with the historical evolution of GOS over 5 periods of 162 years in total: 1) briefly from 1856 to 1945 (90 years); 2) from 1946 to 1975; 3) from 1976 to 2007; and 4) from 2008 to 2020; Part VI, deals with our theory of Perfect Timing; finally, we conclude.

\section{Literature Review}

\subsection{Cycles Since 1741}

The first thing that a ship manager has to understand is shipping cycles. Stopford (2009) contributed in a detailed presentation of shipping cycles, and in particular he recorded the freight rates of dry cargo ships since 1741 (Figure 1).

As shown, 22 cycles recorded along 259 years, or 1 cycle for every 12 years on average. The Wind/Sails were the exclusive means of propulsion till 1871 (130 years since 1741 or 19 years on average over 7 cycles)! Of course, the technology of ship propulsion progressed over these almost 300 years. Moreover,

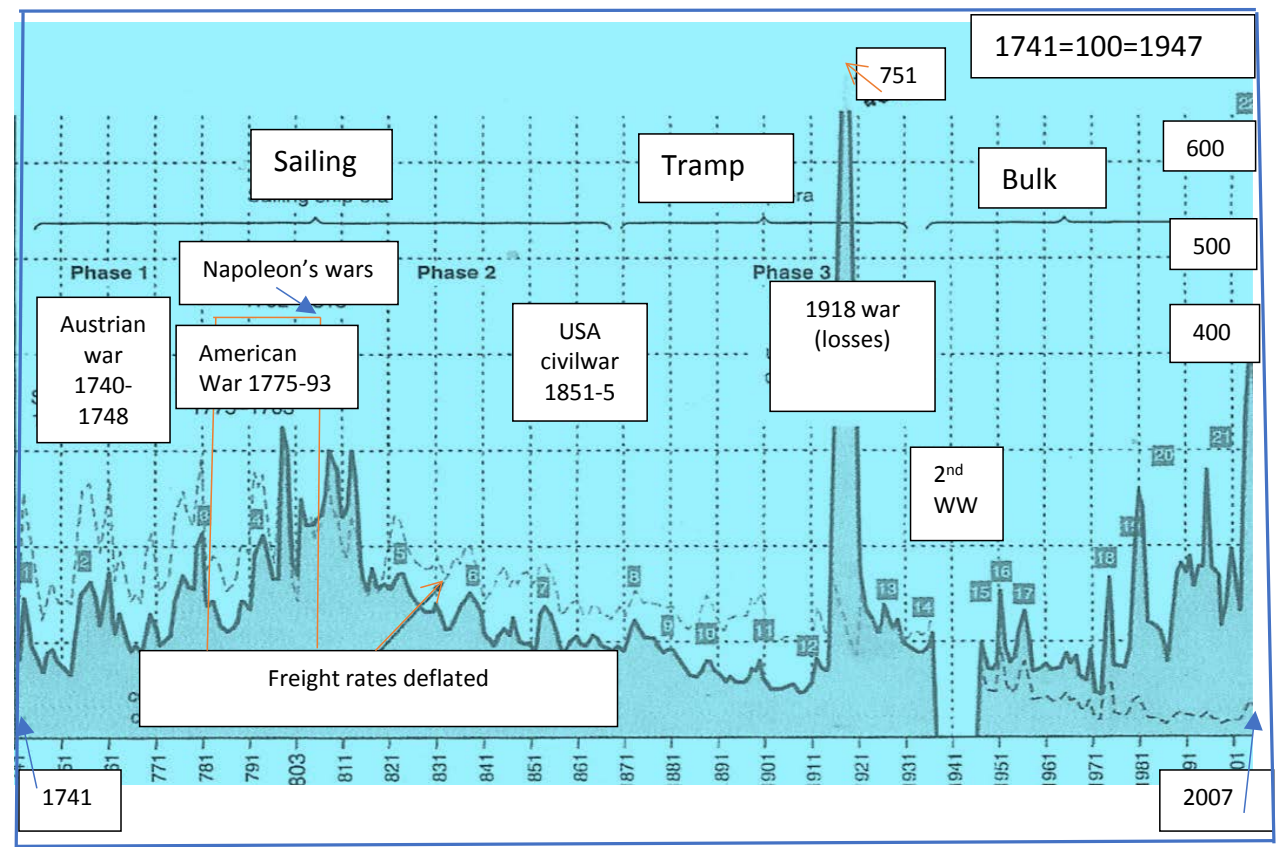

Figure 1. The 22 shipping cycles of freight rates of dry cargo ships, 1741-2007. Source: Stopford (2009), modified, p. 105; 8 war years are missing.

${ }^{7}$ This concerns exclusively ships, owned by Greeks, no matter their flag. 
4 wars $^{8}$ took place since 1740, and par excellence those led by Emperor Napoleon, which lasted 24 years (1792-1815)!

\subsection{Tramps}

In 1871, the type of ships, called "tramps", appeared. The title is un-related to propulsion. In addition, one may be misled to take, e.g. "bulk carriers", (successors of tramps), as ships entirely different from tramps. In fact, it is not the propulsion which differentiates tramps from non-tramps, but speed.

\subsection{Steam and 0il}

After wind, steam is used in propulsion, and after steam, oil. The "internal combustion engine" was a crucial invention. It is only during recent decades, due to an aggressive global climate, that the use of a green fuels is sought after, coupled with a device to retain Sulphur. The choice of oil as fuel for engines, (first in private cars), was indeed decisive at that time, though it could be avoided!

\subsection{Demand (Seaborne Trade)}

This in shipping is the King! It "takes" almost all initiatives, and supply (the Queen) responds, as the case may be, but not always successfully (Figure 2). The cyclical behavior of demand is also apparent. Some argue correctly that if demand is cyclical, then prices are also cyclical.

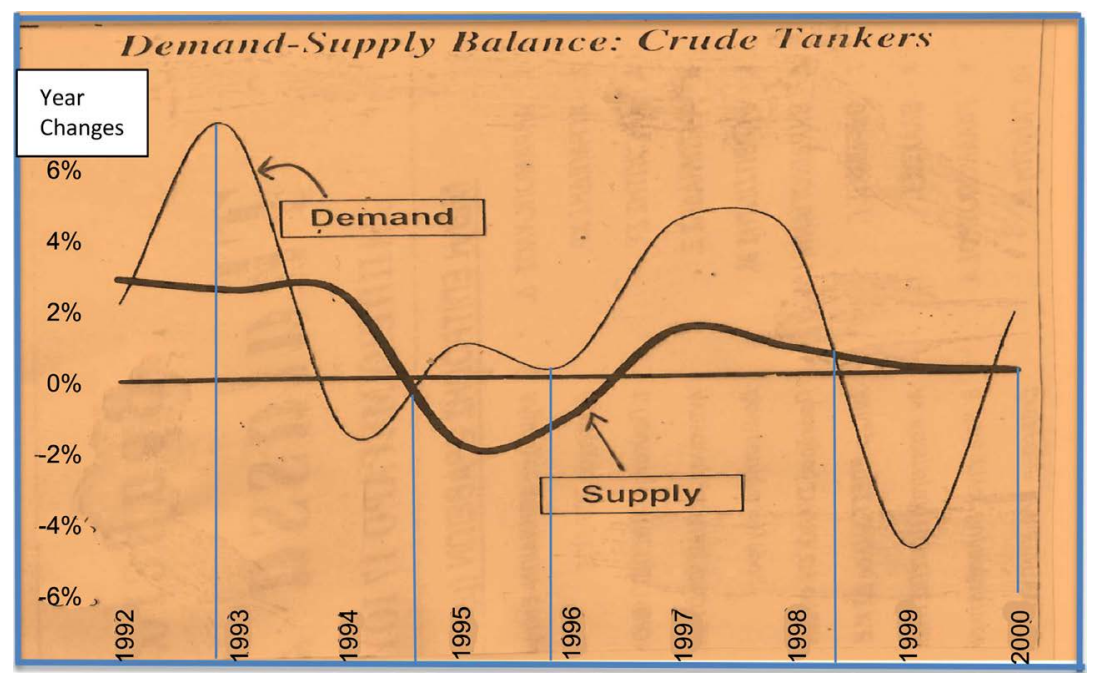

Figure 2. Demand-supply balance for tankers, 1992-2000. Source: Clarkson's, May 2000, modified.

\footnotetext{
${ }^{8}$ Greek shipowners succeeded in "breaking" embargoes one time after another, making substantial extra money (France embargo; Cuba embargo; and elsewhere).

"Tramp" is a term to characterize a ship which may have not the same ports to load/unload cargo, voyage after voyage. Some call them: "cargo-taxis of oceans". The metaphor "tramp" comes from the fact that certain men/women, in old times, had no specific place to stay (home), but they wandered around from one place to another, seeking employment or a sexual partner... Moreover, people had to distinguish tramps from liners. Liners have a pre-announced, pre-advertised, schedule of visiting specific ports at specific days, times, many agents etc. Greeks specialized in tramps for reasons that cannot be explained here.
} 
As shown, demand's \% increases/falls are not followed by analogous timely supply \% increases or falls, e.g., the rise of demand in end 1992 by $7 \%$ faced supply's apathy. Surely, shipowners are people of waiting \& see. Also, the fall in demand in 1999, also faced supply's apathy. For the fall in demand in 1994, supply responded, but with a year delay! Of course, the supply in order to respond to demand needs to pass construction time (of ships); this period varies according to shipping cycle phase.

In more detail, in end 1992 demand increased by 7\%, while supply increased by only $2.5 \%$. One must take into account also that Demand is measured in billion tons, while supply in million tons. As a result, Supply had to increase in greater percentages than demand. Moreover, in late 1994 till 2000 supply fell behind demand except in 1999. It seems that supply was affected by demand from end 1995 to early 1999 and in 1999-2000.

As Alfred Marshall (1842-1924) wrote: the price (the freight rate here) is determined by demand and supply, the same way that the scissors' two blades cut paper!

\subsection{Cycle's Duration}

Taking e.g. the period from 1741 to 1870 ships faced a cycle when they were about to be scrapped, i.e. at their $\sim 19$ years of age on average! Shipowners were happy at that time, if they have built ships when cycle started. It is also recorded that the duration of a boom was shorter than the duration of a recession (with the exception of the 1988-1997 boom, which lasted 10 years!).

Stopford (2009: p. 106) calculated the duration of shipping average peak as equal to 3 years (1947-2007) and the duration of average trough as equal to 5 years. Thus, a vessel, in her life, will face 4 peaks and 4 troughs. Short booms mean that supply responded fast to demand. It also means that long time charters are preferred... Good things, however, do not last forever...apart from being shorter.

Professor Harlaftis (1996), the main modern historian of GOS, attributed GOS' miracle to the ability of shipowners to form partnerships with persons exclusively coming from the same place, and having also certain close relationship one with the other (next of kin); moreover, Greek shipowners had a natural motive to seek-after-all-opportunities ${ }^{10}$; they also adopted a strategy concerning the proper choice of cargoes, and they used to "buy when other sell and sell when others buy". We will try to make this last one meaningful. This general rule is perhaps advisable when one deals par excellence with shares...

\section{Part 1: The Way the Tanker Market Functions}

Six figures were used, referring to the 1979-1989 depression, which hit tankers par excellence.

\subsection{The Tanker Economics Mechanism}

Seaborne trade (=demand) for various reasons may fall. Given supply, and dis-

${ }^{10}$ This is indeed a characteristic of Greek shipowners. 
tances, this will cause a reduction in freight rates. Shipowners stop to order, and buy ships. If the recession continues, then they "drive" their ships to lay-up, and finally, and after sometime, they scrap them.

Scrapping takes place if there is no hope for a vessel to earn something above her cost of operation, say after ${ }^{11} 3-4$ years of trying, maintaining, waiting and see. The unknown factor in this process is time. Time varies as volumes involved may be different each time.

\subsection{A Tanker Diagrammatic Exposition, 1979-1989}

The "world oil trade" is shown in Figure 3. It fell 50\% down of what used to be in 1979 and in 3 close occasions: 1983, 1985 and 1987! As a result, tanker freight rates fell (Figure 4).

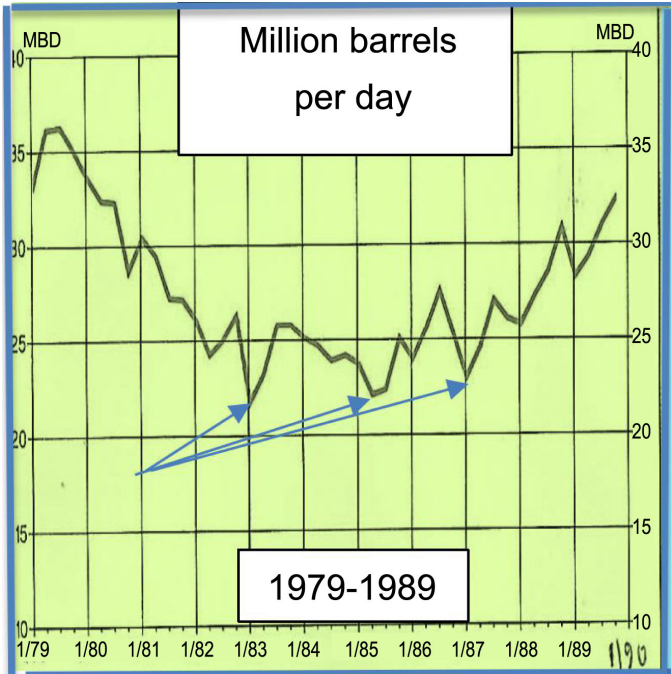

Figure 3. World oil trade, mb/day, 1979-1989; Source: Platou A/S report; both modified.

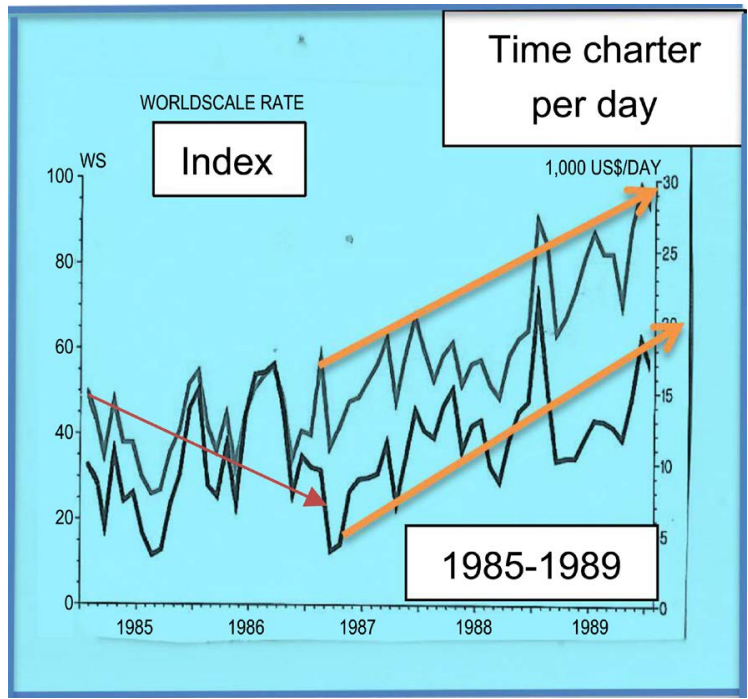

Figure 4. Tanker freight rates, 1985-1989; Source: Platou A/S report; both modified.

${ }^{11}$ Our research experience shows that scrapping removes about $1 / 3$ only of excess supply per year. 
As shown, the world oil trade fell in Jan. 1983, 1985-86 and in Jan. 1987 (Figure 3; indicated by blue arrows). As a result, the freight rates indices for tankers fell also, though fluctuating (Figure 4; red arrow) during the same years, though since January 1987 tanker freight rates increased (orange arrows) for two sizes of tankers.

Moreover, new orders for tankers fell to a minimum (1982) (Figure 5), i.e. just below $1 \mathrm{~m}$ dwt, out of $16 \mathrm{~m}$ at their peak. Additionally, seventy-five (75) million dwt of tankers were laid-up (1983) (Figure 6) (blue arrow)! There is a

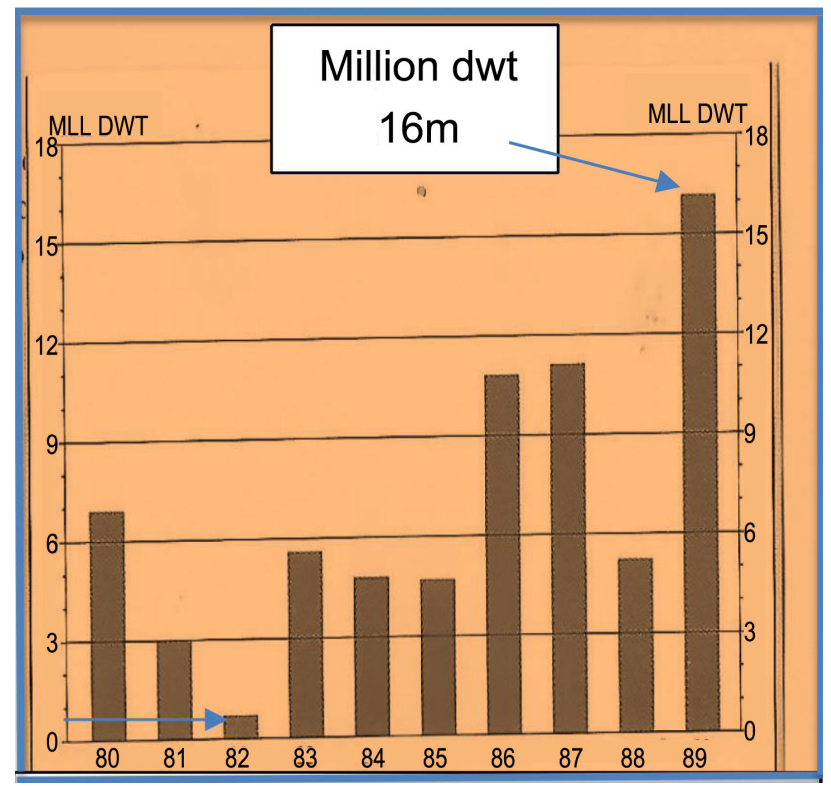

Figure 5. Tanker new orders in million dwt, 1980-1989, 25,000 dwt+ ships. Source: As in previous figures; modified.

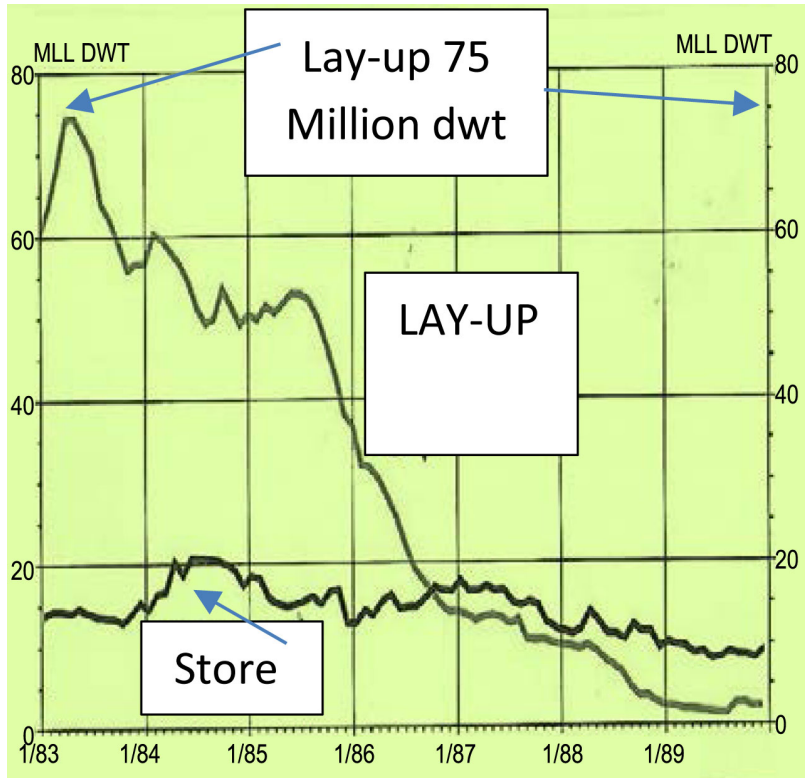

Figure 6. Tankers in lay-up, 1983-1989, in m dwt. Source: As in previous figures; modified. 
proverb in Greek language saying: "A nice day can be recognized from dawn". Dawn in shipping is when there are zero ${ }^{12}$ laid-up ships! Reality, however, is different (Picture 1; as shown the dawn for the laid-up ships is foggy).

Tankers eventually did not escape... death (=scrapping) (Figure 7).

The tanker tonnage in laid-up (Figure 6) is scrapped within 4 years (19821985) (Figure 7). Industry does not rush to scrap, as it knows that this is the final act for ships, but it takes its time, trying to sell them first, or rent them for storage $^{13}$ of oil (Figure $6{ }^{14} ; 20 \mathrm{~m} \mathrm{dwt} \mathrm{in} \mathrm{1984).} \mathrm{Deliveries} \mathrm{are} \mathrm{also} \mathrm{related} \mathrm{to} \mathrm{or-}$ ders some time ago, given the ship building time (Figure 7) of one year or so on

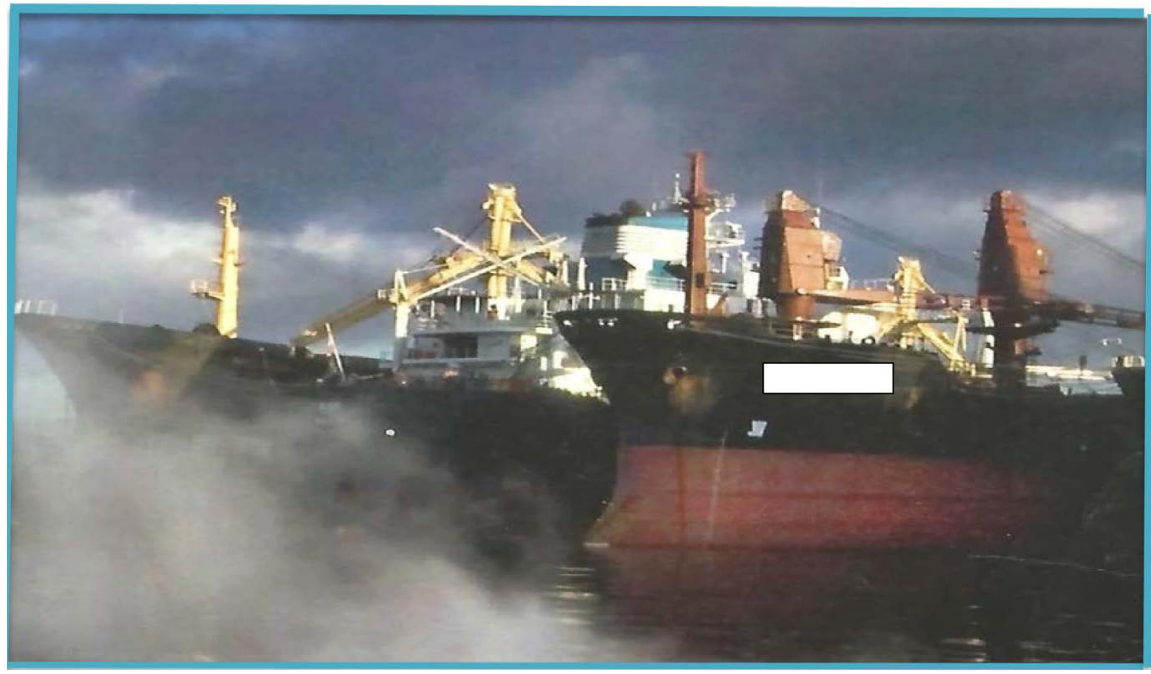

Picture 1. Ships in lay-up, waiting, in fog, for employment. Source: unrecorded; modified.

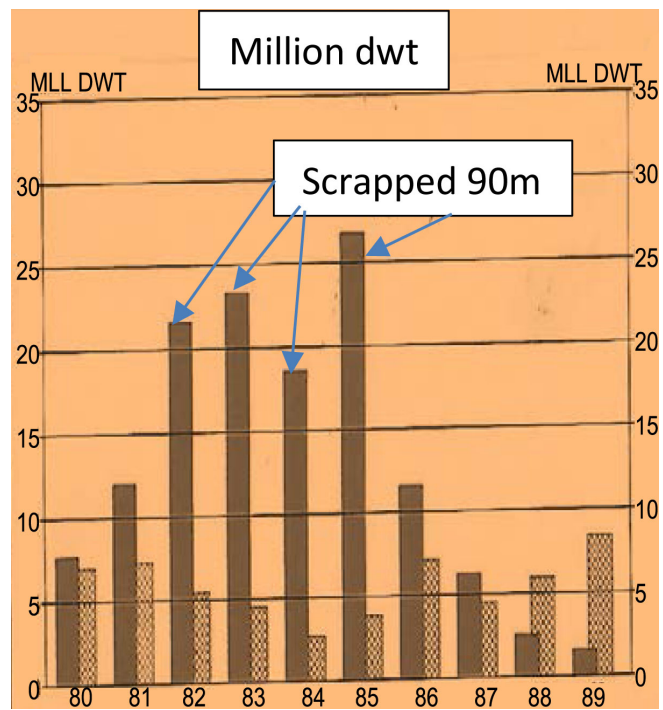

Figure 7. Tanker scrapping \& deliveries, 1980-1989, m dwt. Source: as in previous figures; modified.

\footnotetext{
${ }^{12} \mathrm{~A}$ zero cannot be, but a minimum can be.

${ }^{13}$ One option is also slow steaming.

${ }^{14}$ Tankers can also be used for transport of grain (after cleaning).
} 
average, depending on the phase of shipping cycle. In a depression, ship prices are low (Figure 8), and thus sales are not recommended. In 1983 e.g., tanker prices were at rock bottom, i.e. $\$ 3 \mathrm{~m}$, from $\$ 28 \mathrm{~m}$ in $1980\left(1 / 9^{\text {th }}\right)$ ! 1983 provided obviously a perfect timing to buy ${ }^{15}$ (tankers). At the end of 1982, 13 million dwt of bulk carriers were also laid-up globally, given that after at least 2 years, since $1979,\left(2^{\text {nd }}\right.$ half 1981$)$, depression hit also dry-cargo ships.

\section{Part 2: The Growth Rates of GOS from 1856 to 1945}

The demand for shipping services is always reflected in freight rates (Figure 9), given supply and distances.

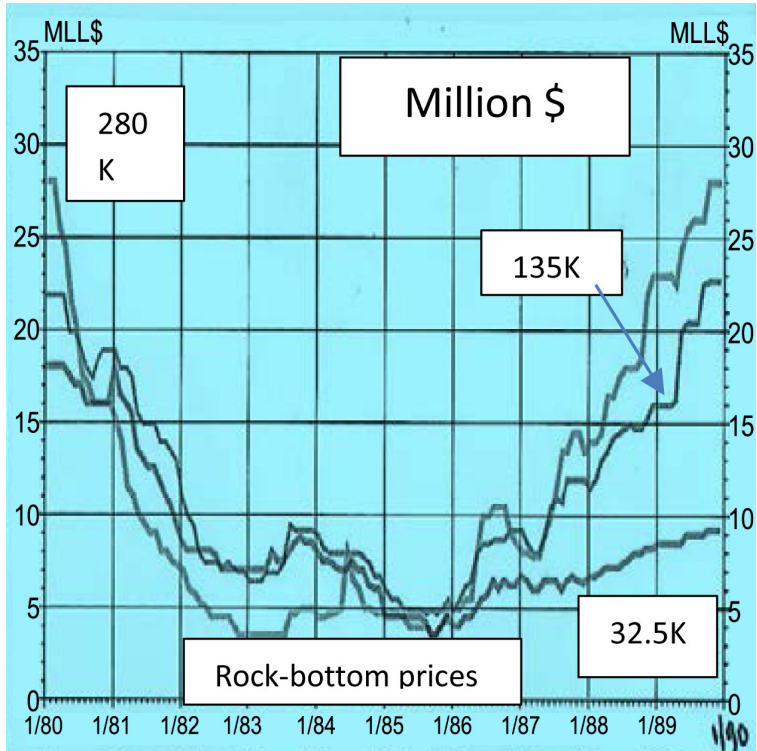

Figure 8. Tanker prices in 3 sizes in $\mathrm{m} \$, 1980-1989$. Source: as in previous figures; modified.

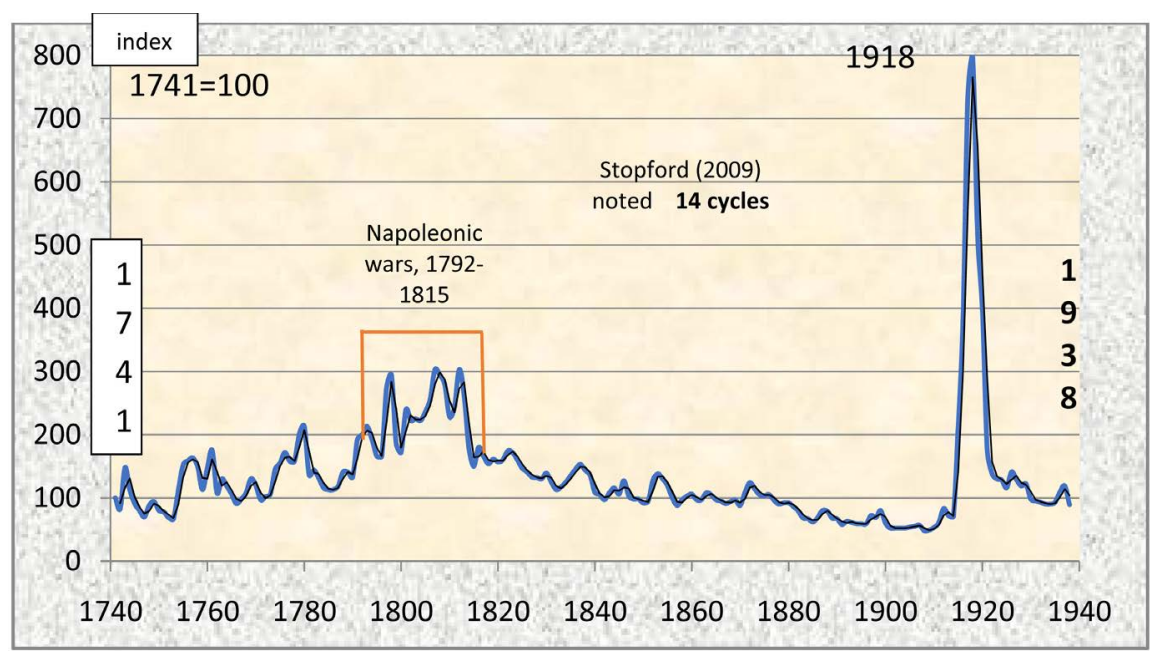

Figure 9. Freight rates for the dry cargo global shipping, 1741-1938. Source: data from Stopford (2009); excel; data for 1939-1946 are N/A.

${ }^{15}$ Creating a competitive advantage. 
The tendency to create cycles (14 years on average in 1741-1938) is obvious; there are, however, superimposed on seasonal and on long waves.

\subsection{Long Waves in Shipping Industry}

The Russian Kondratieff (1892-?) (1950) wrote about (economic) long waves in Capitalism ${ }^{16}$, (lasting 54 or so years on average and ending upon a... war); Schumpeter $(1954)^{17}$ (1883-1950) related long waves... to technology, instead to wars, as follows: 1) the first long wave, from 1790 to 1813, attributed to Steam; 2) the 1844 to 1874 , to Railways; 3) the 1895 to 1916, to Electricity \& Motor. Stopford (2009) attributed the 1950 to 2007 long wave to electrical industries \& electronic ones.

The point that the above 3 scientists missed, however, was that the actual duration of a long wave depends on how long statistical data exists. Goulielmos (2017) proved that long waves in maritime industry were indeed secular $(=100$ years), as shown (Figure 10), using 267 yearly data.

\subsection{GOS' Growth from 1856 to 1945}

GOS appeared on a shipping register, (e.g. on Lloyd's, est. in 1760), in 1856 (Figure 11), owning first sailing and steam ships (Picture 2). GOS' ships, however, were registered in various non-English ship registers since 1830 , as shown by Harlaftis (1996).

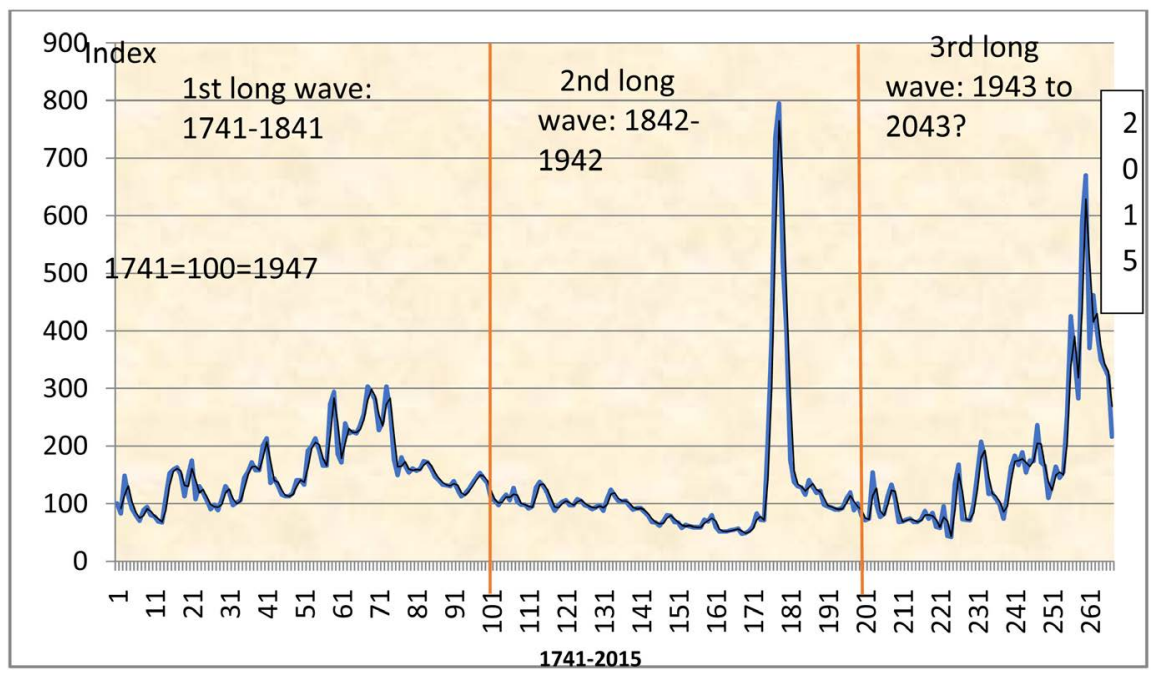

Figure 10. Index of dry cargo freight rates, 1741-2015 (267 years). Source: data due to Stopford (2009) and Clarkson's after 2008 to 2015; 8 years are missing in 1940s.

${ }^{16}$ But not in accordance with Marx!

${ }^{17} \mathrm{He}$ was the economist in favor of monopolies etc., which finally used their abnormal profits to promote businesses. Perhaps this is what Keynes argued about "animal spirits". A similar phenomenon, but not so far examined, is the donations carried-out by Greek shipowners, alive or dead, out of their profits. This role of profits (donations) is not examined by economics and perhaps socialists/communists could say (?): "let businessmen obtain profits as these are spent sooner or later for the common good". This made clear in the case of COVID-19 where many Greek shipowners, and not only, run to support country's health system. Notable examples are the "St. Niarchos", "Alex. Onassis" and "Laskaridis" Benevolent Funds, among a much greater number. 


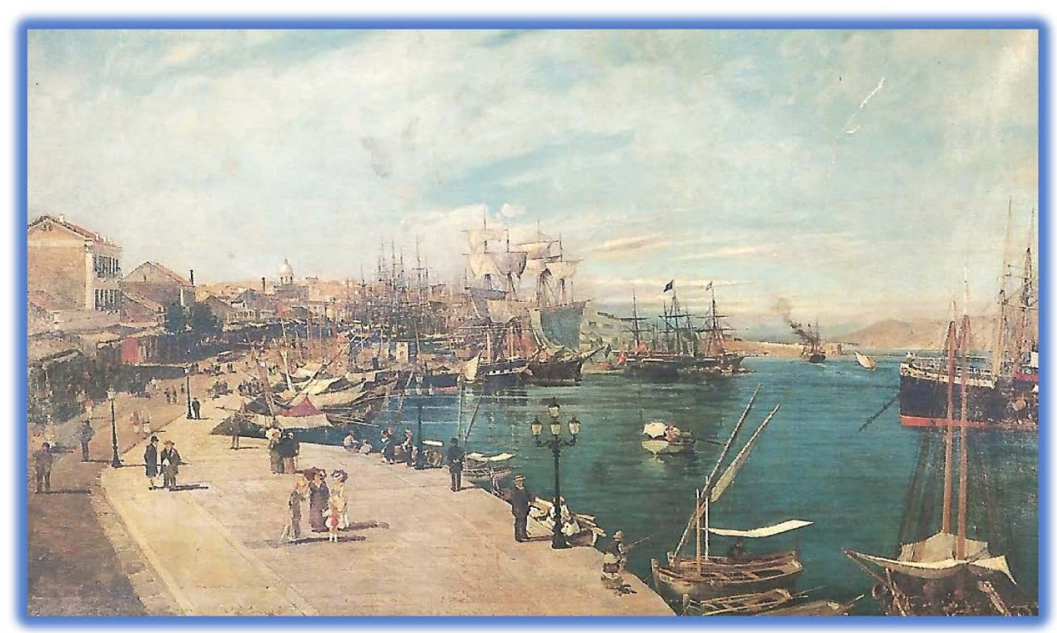

Picture 2. Sail \& steam Greek ships in port of Piraeus in $18^{\text {th }}$ century. Source: Internet; Sailing \& Steam Ships in Port of Piraeus, a painting by Volanakis C. (1837-1907); modified.

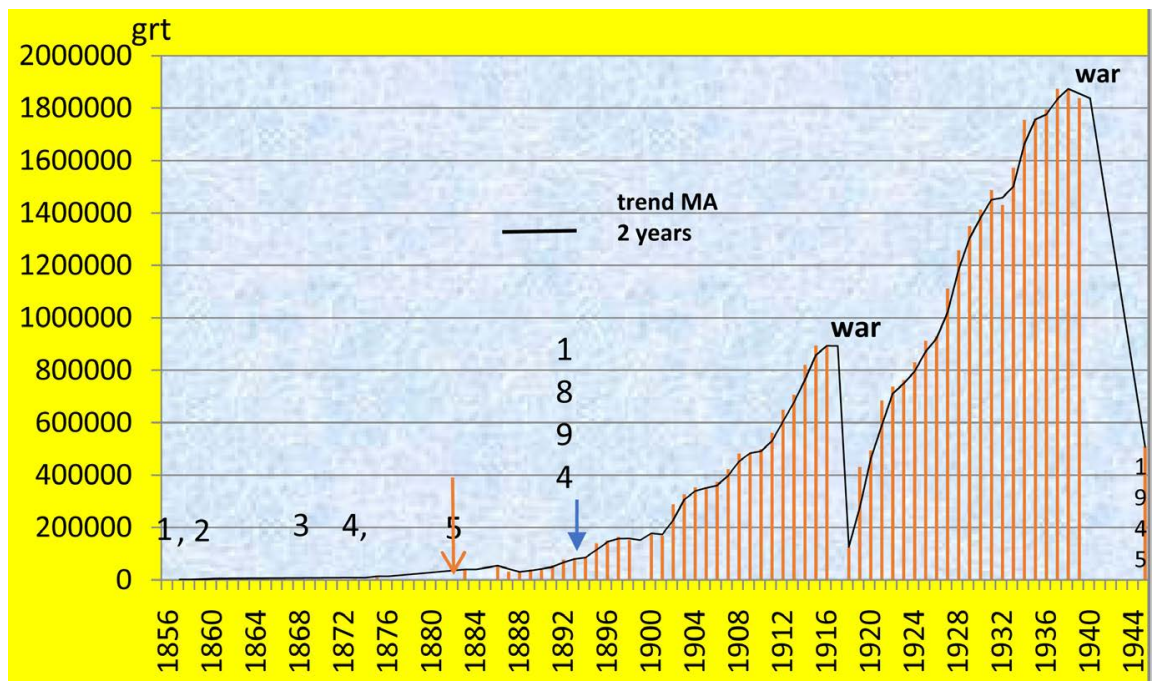

Figure 11. Greek ships in register, 1856-1945. Source: Author; Dunn (nd). Notes: $1=$ $1856-1858=899$ tons; $2=1859=3259 \mathrm{t} ; 1860\left(^{*}\right)=5221 \mathrm{t} ; 1861=29,000 \mathrm{t} ; 1862-1868$ $\mathrm{N} / \mathrm{A} ; 3=1869=29,000 ; 1870-1872=\mathrm{N} / \mathrm{A} ; 1873=7887 \mathrm{t} ; 1874=\mathrm{N} / \mathrm{A} ; 4=1875=13,000 \mathrm{t}$ $\left.{ }^{\star *}\right)$; 1876-1882 N/A.; $5=1883=40,000$ t; $1884-1885=$ N/A; 1899 N/A; 1917: N/A; 1940-1944: N/A; $1945=508,000$ t. $\left.{ }^{*}\right)$ Harlaftis (1996), op. cit., p. 61, recorded in England Greek merchants as shipowners owning 13,537GRT. $\left.{ }^{\star *}\right)$ Harlaftis wrote that in 1875 Greeks owned 2500 sailing cargo ships of which 70 ocean-going.

In 1860 Greeks owned 13,537 GRT, and in 1861 4,609 ships of 29,000 GRT, mostly sailing (Vassiliou, 1961). Notable is that market fell due to a recession in 1894.

The Greek fleet grew fast between 1883 and 1945, except during war years. Also, demand grew rapidly in 1869-1914 and in 1920-1930. It fell, however, in 1930-1939 due to the 1929-1936 depression.

\subsubsection{GOS' War Losses}

The 2 World Wars destroyed most of GOS: in 1918, the Greek tonnage survived 
from $1^{\text {st }}$ WW was only $\sim 126,000$ GRT, against 892,650 in $1916(-86 \%)$; and in 1945 , the tonnage survived from $2^{\text {nd }} \mathrm{WW}$ was only $\sim 508,000 \mathrm{t}$ against $1,873,000$ tons in 1939 (approx.-72\%).

\subsubsection{GOS' Progress, 1920-1940}

In 1920, Greeks had only 6 - 7 shipping offices in London. This period offered low $2^{\text {nd }}$ hand ship prices; Greeks used to put their shipping profits together, (a

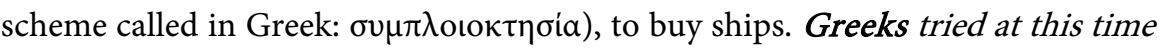
to buy larger and newer ships. A first recorded sign of their unique strategy.

GOS progressed in 1930-1931 and in 1935, reaching the 10th worldwide position, owning 1.4m GRT (1931). The 1929-1936 depression hit par excellence British shipping. As a result, British sold ships for which Greeks were buyers! British in particular had the policy to sell ships approaching their $3^{\text {rd }}\left(4^{\text {th }}\right.$-yearly) survey (i.e. before 12 years of age) (Goulielmos, 1974) and Greeks to buy them... In 1933, the depression retreated, and Greeks "rushed" to order and buy ships, reaching the $9^{\text {th }}$ world position owning $1.5 \mathrm{~m}$ GRT.

As shipping depression (1929-1936) was over, and freight markets improved, Greeks already accumulated gross revenue of $£ 10 \mathrm{~m}$. As a result, new orders placed in British shipyards, and additional Greek shipping companies established in UK. In 1939, Greeks owned 1.88m GRT and by 1940 they approached the $2 \mathrm{~m}$ GRT mark.

\section{Part 3: GOS' Growth from 1949 to 1975}

GOS in its evolution from 1949 to 1975 showed two distinct rates of growth (Figure 12): 1) 1949-1962 and 2) 1963-1975.

As shown, GOS increased about 6 times from 1949 to 1962, starting from 2.38m GRT, ( $2^{\text {nd }}$ world position; 1961); also, it reached $48.3 \mathrm{~m}$ in 1975 (about 20 times increase since 1949). To judge GOS' growth we established a criterion: i.e. we calculated its typical growth (=most common), or mode ${ }^{18}$ in statistical terminology

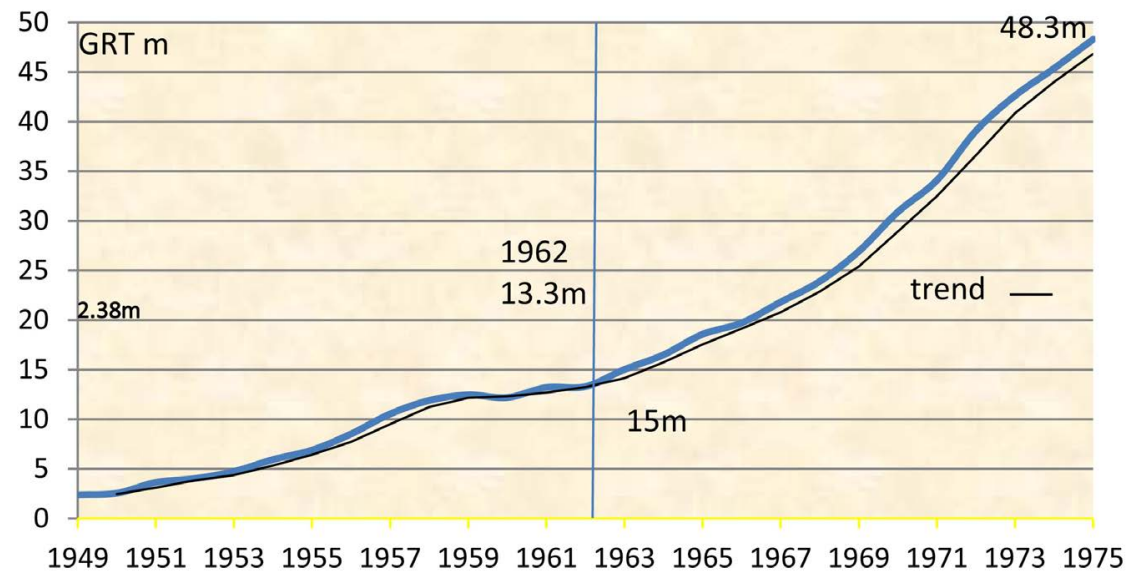

Figure 12. The growth of GOS, 1949-1975, (end of year). Source: Author; data from "Naftica Chronica" (1975).

${ }^{18}$ The Mode $=$ Mean-3 (Mean-Median). 
(Appendix 1) This found equal to $4 \%$ for GOS from year to year in GRT, GT and DWT over the last 70 years (since 1949; 2 years data are N/A).

\subsection{Freight Markets, 1947-1962}

As the world markets re-opened in 1945, dry cargo freight rates increased and continuously rose, till 1947 (Figure 13). Soon, however, a falling trend started, and the pessimism among ship-owners returned (1949).

The market is clearly cyclical: where an increase in rates due to lack of supply, and/or a rise in demand, given distances, induces a higher shipbuilding production, and given that demand is not coordinated to supply, as we showed above (Figure 2), freight rates fall... Ships emerge in greater numbers than needed!

Tanker freight rates (Figure 14) had a similar cyclical pattern.

Given that only scrapping may correct permanently ${ }^{19}$ an oversupply of existing, rather old/uneconomic, ships, demand for ship space re-appeared strong latter, (at the end of 1950); orders for new ships stopped just prior to it. When the memory of $2^{\text {nd }}$ WW started to faint-out, Korean War (1950-1951), revived it, by creating a "stock-building panic".

Between 1945 and 1950 freight markets stabilized, while between 1951 and 1955 improved. Greeks rushed to order and buy ships. Seaborne trade increased by $16 \%$, but this was short-lived (12 months), followed by import restrictions. These factors led to the laid-up of ships by 1953, the other classical result of a shipping crisis. The crisis deepened, however, covering also the $1^{\text {st }}$ half of 1954 .

Greeks considered 1956 as the year when GOS miracle started! Data do not

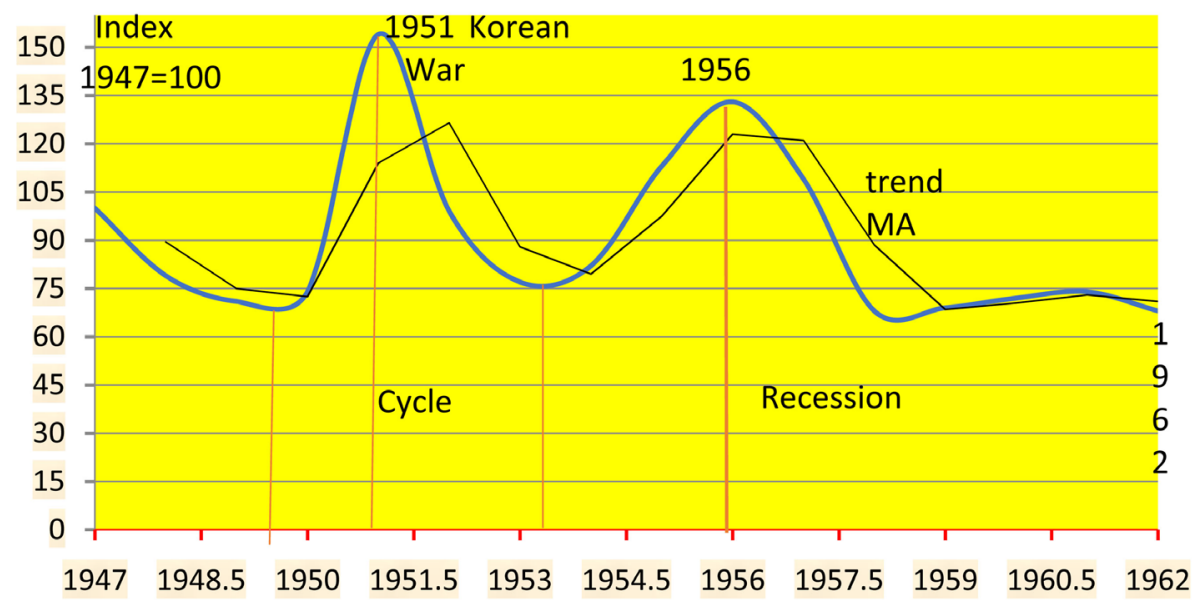

Figure 13. The freight rate market index of dry cargo, 1947-1962. Source: author; data from Stopford (2009).

\footnotetext{
${ }^{19}$ Supply is temporarily reduced by lay-up (getting ships away from market). This is so because ships have a long life-round 32 years on average-and their lay-up is caused whenever freight rates are below their operating cost. The effectiveness, however, of scrapping and of lay-up, to bring equilibrium, depends on the (excess) volumes involved, given demand/distances. Shipowners usually wait for a number of years, (say 3 - 4 years), having their ships in lay-up, before they decide to scrap them. Of course, they try to sell them. Economies of scale added a new feature to scrapping, because large ships provide now several million \$, and thus a serious liquidity during a bad market!
} 


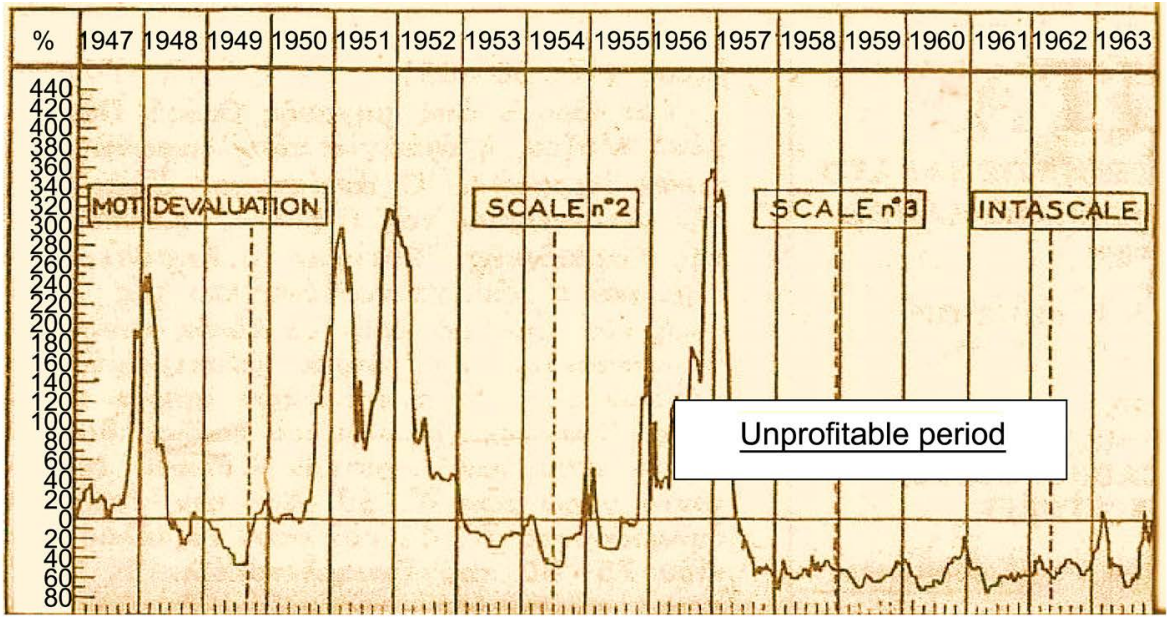

Figure 14. Tanker freight Rates, 1947-1963. Source: unknown; notable is the low levels in 1957-1963; the tanker index MOT depended on Sterling devaluation.

support this, however, as the miracle started in 1946 with the 100 Liberties they bought; good markets maintained in 1949-1950; continued in 1957-1959 (except in 1960); and in 1961. However, the growth can be faster when fleet starts from low levels, as GOS did, rather than when fleet is grown-up.

Orders placed then for $\sim 6 \mathrm{~m}$ tons of a total value of $\$ 1 \mathrm{~b}$, of which 150 units in Japan! GOS increased from year to year 30\% in 1950-1951 and 26\% in 1954, 1956 and 1957 (Appendix 1)! This considered as miracle. Greeks were traditional customers of UK shipyards, but they realized that British shipyards could not offer the lower prices and higher finance, which Japanese could! In addition, after 1956, Suez Canal nationalized, and freight markets improved.

\subsubsection{The Liberty Ships}

In 1946 (15/11), a big push forward to GOS was given by the 1m GRT (of 100, or so, ships of Liberty type), given ${ }^{20}$ by USA government, under favorable terms ("lend-lease"), to their allies for their help in world "Freedom" during $2^{\text {nd }}$ world war. Such an ally was Greece.

\subsubsection{Oil Consumption from 1955 Onwards}

Characteristic is that, since 1955, oil consumption increased continuously, and during severe winters, reached a $10 \%$ increase p.a. Shipowners, and Onassis, turned unrestrained to tankers, where a time charter could pay-back ship's capital cost within 5 years! The intense demand in 1955-1956, however, led to an over-ordering of ships, another classical (bad) reaction of shipowners.

\subsubsection{Shipping Finance... in Lack in 1950s}

This was the first time in history of shipping finance, when funds demanded for shipping loans proved inadequate, though funds were coming also from... "Pension Funds ${ }^{21}$ "! Then shipyards decided to help by providing $80 \%$ finance on

${ }^{21}$ Onassis was the first to borrow from a life Insurance company in USA $\$ 42 \mathrm{~m}$ ! 
the price of a new vessel! As we stated elsewhere, finance is the necessary $y^{22}$ condition for a fast expansion, but not the sufficient one! The sufficient condition is always to be efficient and effective in what you are doing (mission).

\subsubsection{Industrial Production ${ }^{23}$}

It fell $4 \%$ in 1958 , which caused a fall in trade, something which had to occur since 1932. While demand was thereafter intense, increasing from $990 \mathrm{~m}$ tons (1959) to $1790 \mathrm{~m}$ tons (1966) (or an $80 \%$ increase in 7 years), the production of shipbuilding production doubled, embodying also great "economies of scale". As a result, freight rates returned to profitability in late 1967. As we have stated elsewhere: "the prosperity of Shipbuilding, is responsible for... the misery of shipping"!

All reactions of shipowners we studied are reactive, with the exception of late C.M. Lemos. The after 1956 shipping crisis indeed alarmed people of Greek shipping to the extent that the late Prof. of shipping economics El. Georgantopoulos (born in 1916)-worked-out this issue in his doctoral thesis (undated).

\subsection{Freight Markets, 1963-1975}

The spot dry markets moved into recession for 3 years (1970-1972). The owners, who could predict this recession, signed (long term) time charters ${ }^{24}$ (Figure 15).

As shown, freight rates, for dry cargo ships fluctuated below 100 units (=1947), till 1972, when a recession emerged, extending to 1975, which interrupted by 2 prosperous years: 1973 and 1974 .

In tankers, years 1967 and 1970 made the whole good difference (Figure 16).

As shown, tanker freight rates, after a long period of low levels from 1957 to mid-1967 ( 10 years), showed a cyclical pattern, with peaks in 1967 and in 1970.

\footnotetext{
${ }^{22}$ Onassis "used" the funds of other people, deposited in banks, for the first time in history of GOS. Traditional Greeks used only their past profits to build ships as they knew that a fall in the market upon delivery of a ship, under a heavy loan, was adequate to lead a shipping company to bankruptcy! Modern shipowners-aware of modern finance-they know where to find the funds they need at the best available terms (timing-amount-interest-tenor-degrees of freedom etc.). These will grow faster (e.g. Frangou A; Vafias $\mathrm{H}$ ) by creating a competitive advantage. Onassis $1^{\text {st }}$ proved that a shipping company can grow very fast only by external finance. This capitalistic method is which cast people in two classes: those that take the risk to borrow, called entrepreneurs, and those that take no risk and "park" their savings in banks for the first to borrow, called customers... Capitalism is a clever flexible system. It does not like hoarding, however, which caused by last depression (due to sub-prime house loans). This was the most serious impact of the end-2008 depression... to turn people to keep their money under mattresses, and shake people's confidence in banking system...Banks have to restore confidence in them and resume their essential role to provide loans to entrepreneurs and managers. The banks' role is not to make their senior staff rich!

${ }^{23}$ This is considered as a proxy for shipping demand.

${ }^{24} \mathrm{~A}$ time charter protects shipowner from a subsequent fall of spot freight rates. But a time charter is as good as charterer, and shipowners must have a clause for the hire to increase as global inflation increases, as ship cost increases overtime. In good markets a long-time charter is beneficial. The "time-charter versus spot charter strategy" bears risks. Charterers try to fix a hire below a high spot rate prevailing, to discount future. Charterers bear also the risk for fuel oil increases during hire as well as port dues and load/unload ones. Conservative Greek shipowners (believing in "is better one bird in hand than 2 in the bush") in the 2003-2008 boom, stayed outside spot markets, thus losing the opportunity to become multi-millionaires faster...But forecasting is not their strong card as anybody else.
} 


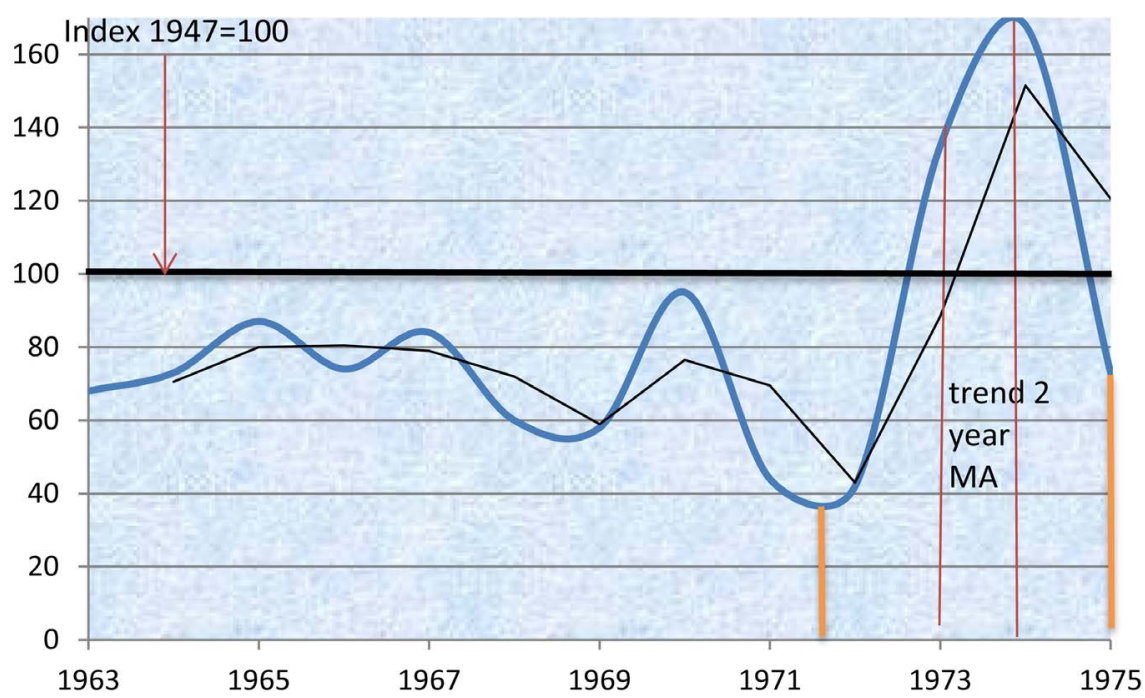

Figure 15. Dry cargo freight rates, 1963-1975. Source: author; data from Stopford (2009).

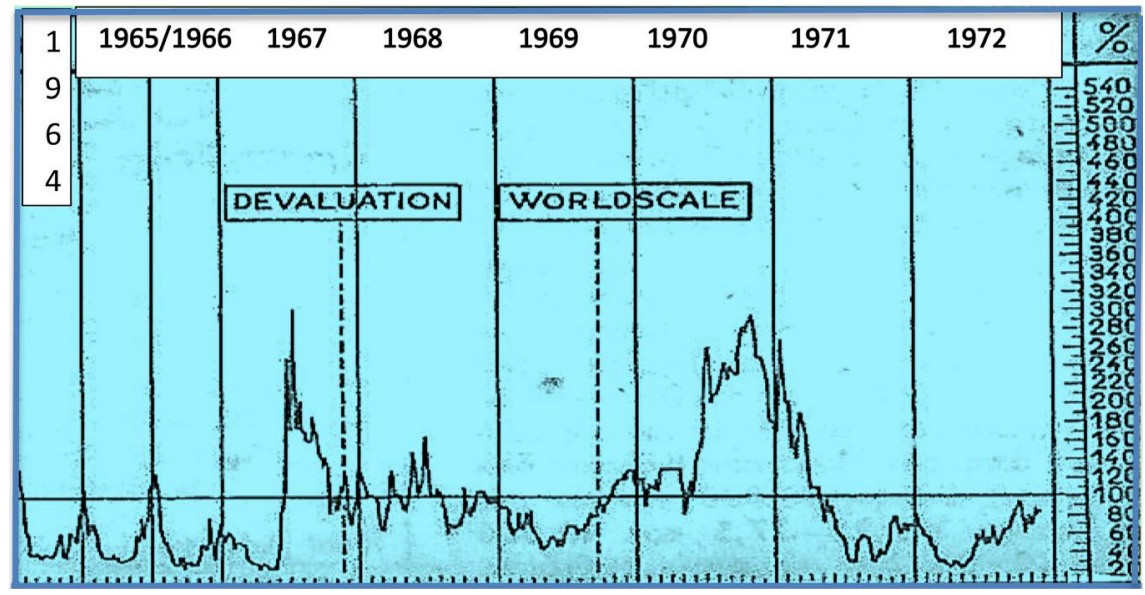

Figure 16. Tanker freight rates index, 1964-1972. Source: not recorded; modified.

\section{Economies of Scale}

Gradually, since 1956, in a type of a tanker, called ULCC (Ultra large crude carrier; >2 million barrels; c. 1963) has appeared. GOS owned 3000 ships of $66 \mathrm{~m}$ dwt in 1973. In year 1975 , however, problems emerged, where only $\$ 2$ b devoted by Greeks to buy ships; in addition, the crisis in tankers extended to dry cargoes; GOS owned 48.3m GRT then (1975). The demand for tankers fell between 1973 and 1988 (15 years!).

\subsection{GOS' Growth (1961-1975)}

The growth during this period was more intense (in GRT), where GOS increased almost 4 times, from about $12.9 \mathrm{~m}$ to $48.3 \mathrm{~m}$ GRT. Freight markets fluctuated and international various events occurred, i.e. Cuba and Vietnam Wars.

The most important event, in 1967, was the "Six-Days War" between Israel and Egypt, and the $2^{\text {nd }}$ long Suez Canal closure. This closure lasted 7 years and provided a prosperous period to shipowners by prolonging sea distances. Then, 
TAR line, (a pipeline), cut back is production in 1970 (15m tons capacity) and Libya's oil production reduced; which, in 1973 nationalized.

In 1966-1970 shipowners were very active with good freight markets, and as a result Greeks placed many orders. This is really also the period of further economies of scale, where tankers reached 300,000 dwt each. SD14 types of ships emerged, (end 1967), which destined to replace the smaller liberties. As economies of scale intensified and the individual shipments rose, shipping grew by leaps and bounds.

Especially 1970 and 1972 were 2 remarkable years for the growth of shipping demand; seaborne trade rose by $78 \%$ (1966-1973) (except in 1971). The peak of the period, however, emerged in 1973, where during summer, the time charter rate for a VLCC doubled, from $\$ 22,000 /$ day to $\$ 44,000$. This had also its impact on ship prices, where a VLCC obtained a price of up to $\$ 73.5 \mathrm{~m}$ from $\$ 26.4 \mathrm{~m}(2.8$ times dearer)! A Perfect Time to sell.

\section{Part 4: GOS' Growth from 1976 to 2007 (32 Years)}

Greek shipowners are optimistic people; they ordered ships in 1976, while crisis marched-well into 1978-1979, hitting tankers par excellence. Greeks owned 5000 ships of 53m GRT in 1979. Their rates of growth at the time were low or negative (Appendix 1).

Greeks by coincidence had a lower tonnage in Tankers in the $2^{\text {nd }}$ half of 1981, vis-à-vis dry cargoes, and given also that 2 years passed between energy crises (1974-75; 1979) and that of dry cargo crisis, Greeks somehow had the time to get prepared to face the coming depression. But this depression was serious, lasting 6 continuous years, and it was also deep. About 100 small shipping companies deleted from Greek shipping list due to bankruptcy! The depression should normally have lasted 4 years, not 6 , but "Sanko shipping company of Japan", comprehending shipping cycles wrongly, embarked in an extensive shipbuilding program of several million dwt (Stopford, 2009: p. 126).

\section{Ships in Scrapping}

Though lay-up is a similar situation as when a patient enters into a hospital in emergencies, scrapping is when ship death occurs! Industry's real situation is shown by the volume of ships scrapped, having no further hope to earn something above their operating cost (Figure 17).

As shown, scrapping peaked in 1985, with $\sim 6 \mathrm{~m}$ GRT, or $\sim 13 \%$ of the fleet. This time was also the peak of shipping depression, 1981-1987, mainly for dry cargo ships. The crisis in both tankers and dry cargoes started in $1975(1.5 \mathrm{~m}$ GRT scrapped), and went well into 1988 (1.1m GRT), and in 1992-1993-1994 (2.1m - 3.4m \& $1.2 \mathrm{~m}$ scrapped). To define, however, the exact timing of scrapping, one has to go back to the facts occurred 3 - 4 prior years, as mentioned.

The freight rates in dry cargo market for 1976-2007 were (Figure 18), as follows. 


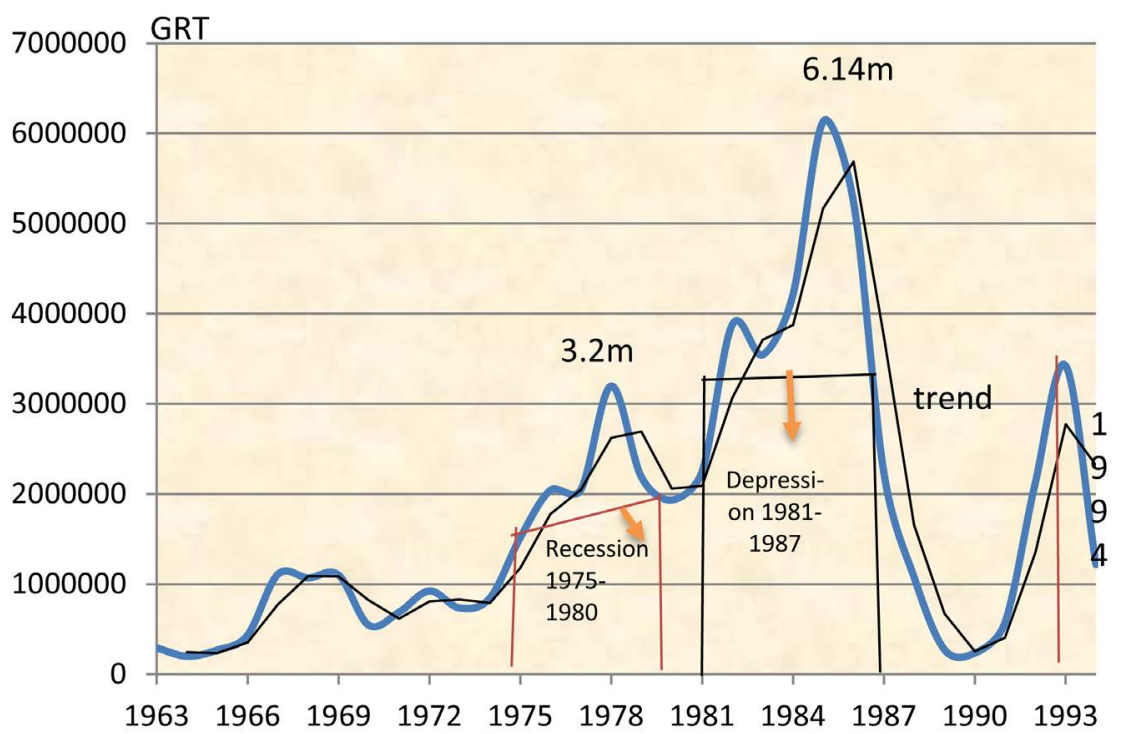

Figure 17. GOS Tonnage scrapped, 1963-1994 (in GRT) (32 years). Source: Data from "Naftica Chronica", various yearly issues.

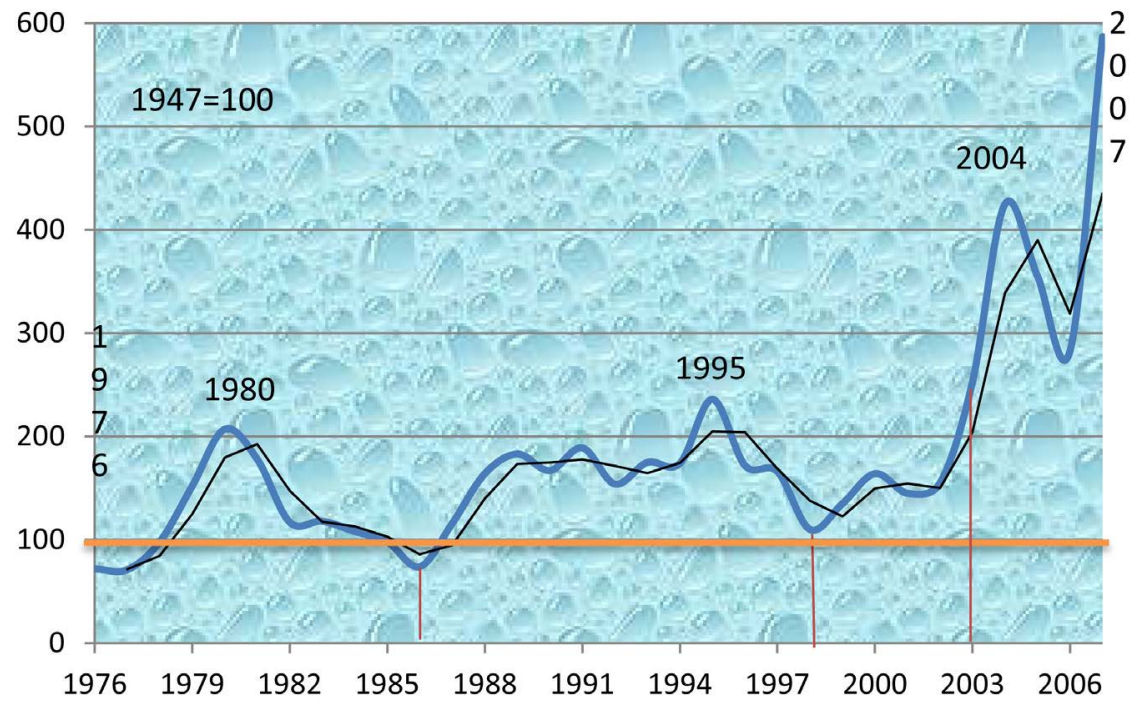

Figure 18. Dry cargo ships freight rates, 1976-2007. Source: author; data from Stopford (2009).

As shown, freight rates peaked in 1980, 1995 and 2004; but the real fortunes were made between 2003 and 2007, till end-2008 (almost 8 years)! In tankers, the 1979 was exciting; 1988 was a good year; and 1989 even better; 1996-1997 were better comparatively; 2000 was extra prosperous, as well 2004; in 2007-2008 freight rates peaked high. This period is the golden age of shipowners, we believe, and is related to China's growth primarily, destined to be terminated by the end-2008 depression and the COVID-19 pandemic in early 2020.

One must take into account that a long prosperous period of extremely high freight rates, like in 2000s, made shipowners capable with abundant profits to seek opportunities, which everybody admitted in 2009 and thereafter that the 
last crisis 2009: definitely brought!

\section{Part 5: Growth of GOS, 2008-2020}

The picture of dry cargo freight rates, between 2008 and 2015 is given below (Figure 19).

As shown, the decadence in freight rates of dry cargoes is apparent during 2009-2013 depression. This had also its impact on GOS, which made it stop growing for about 2 years (2008-2009). GOS among other 8 powerful sea powers came 1st in capacity (dwt) (Figure 20) between 2007 and 2018.

As shown, GOS recovered from the end-2008 banking crisis, and almost doubled till 2018! This is a par excellence fast growth. The fleets of Japan and Germany fell back. Notable is China, which in only 4.5 years, doubled its dwt from $100 \mathrm{~m}$ to $200 \mathrm{~m}$ (2010-mid-2014)! Most of the other 5 nations had a horizontal

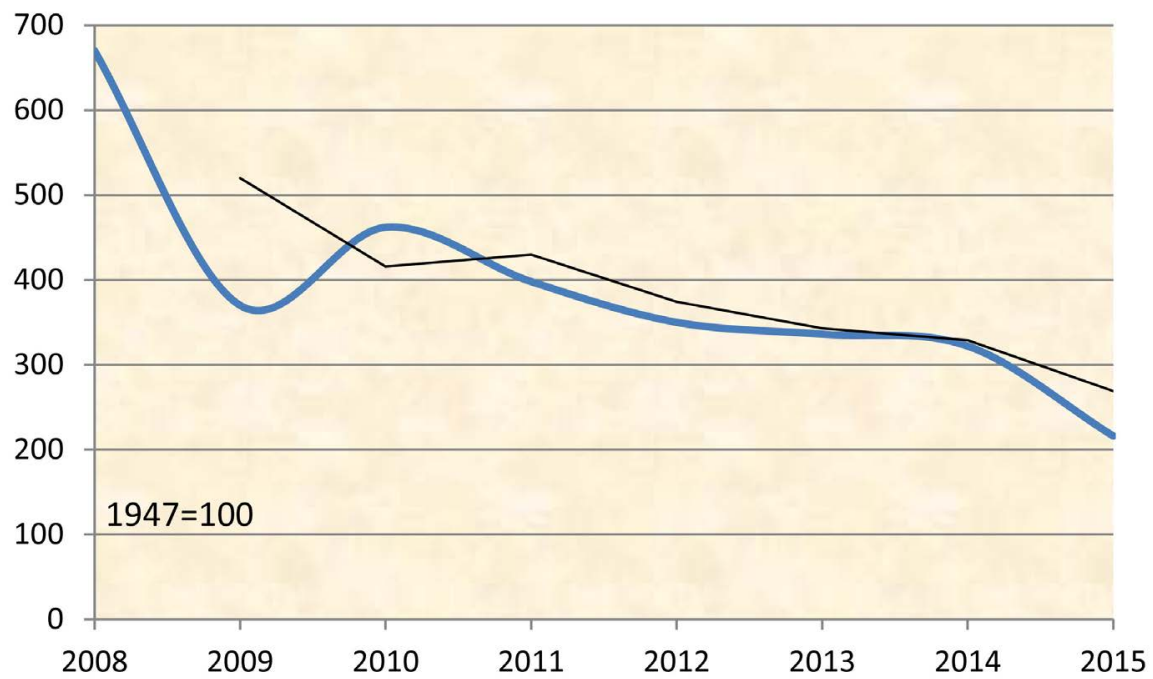

Figure 19. Dry cargo freight rates, 2008-2015. Source: author; data from Stopford (2009) and Clarkson's.

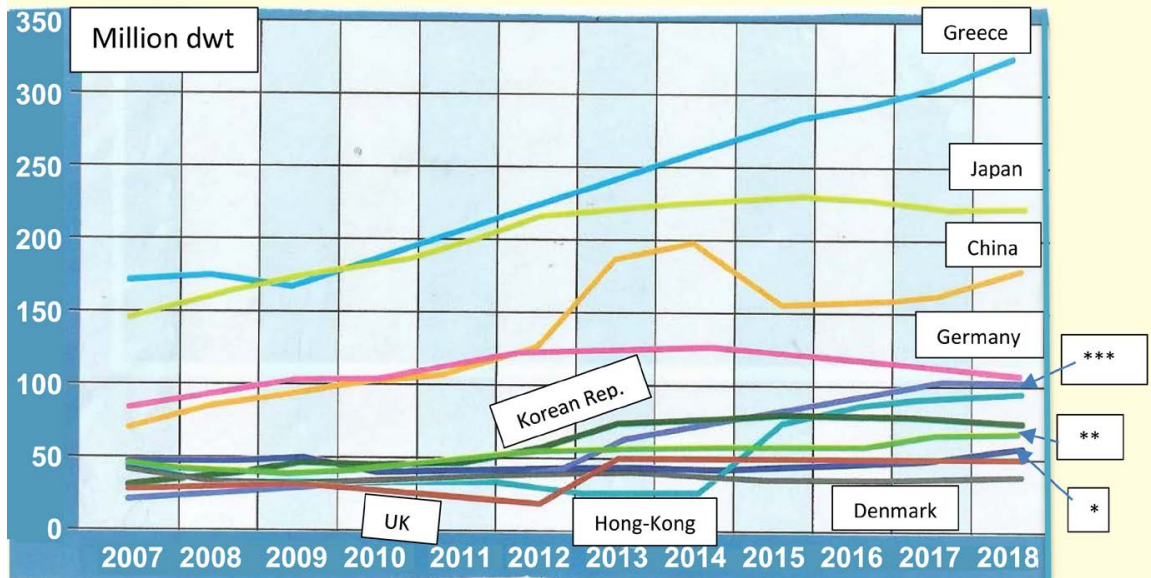

Figure 20. Global fleets by ownership, 2007-2018, in dwt; ships > 1000 GT. Source: UNCTAD; $\left(^{*}\right)$ Norway $\left(^{\star *}\right)$ USA $\left(^{\star * *}\right)$ Singapore. 
(steady or falling) evolution, except Hong-Kong and Singapore. China, we foresee, in future, would become the first global sea power ${ }^{25}$ surpassing Greece. COVID-19 caused problems to ships preventing them to carry-out repairs in China and other areas, where quarantines were in force; and also, they could not send or repatriate crews to/from quarantined ports...

An additional picture is given by data from GSCC covering large ships of over 1000 Gross (Figure 21).

As shown, GOS presented a stall in its growth during 2008-2013 depression and in 2018-2020, though it doubled finally, since 2002!

\section{Part 6: Our Theory of Perfect Timing of Shipping Investments}

Our Perfect Timing theory is related to the following 4 decisions: 1) To place an order for a newbuilding at a minimum price, and on delivery, her freight rates to be at maximum. 2) To buy ships when their prices are rock-bottom, and when delivered their freight rates to be at a maximum... 3) To sell all ships owned smaller and older and 4) to buy ships larger and newer. This policy is win-win.

PT has a crucial meaning as it creates a competitive advantage providing a lower capital cost, which covers about $50 \%$ of total cost in ships newly-built and about $30 \%$ in $2^{\text {nd }}$ hand ones! It also provides economies of scale and economies of smaller age. Surely, behind it is the Greek cost leadership policy.

To apply PT, however, one needs... cycles! This may sound strange, but one cannot apply PT, if variables do not change adequately... Some say that this strategy is already known as "asset-play", but we believe our theory is broader. Apropos is that when Greek shipowners are asked about cycles, they say: "we know that we have to live with cycles" like with we learned to live with "earthquakes."

Our experience is that certain Greek shipping managers committed no doubt mistakes in applying PT, as e.g. a Greek company when a ship had a fall in her

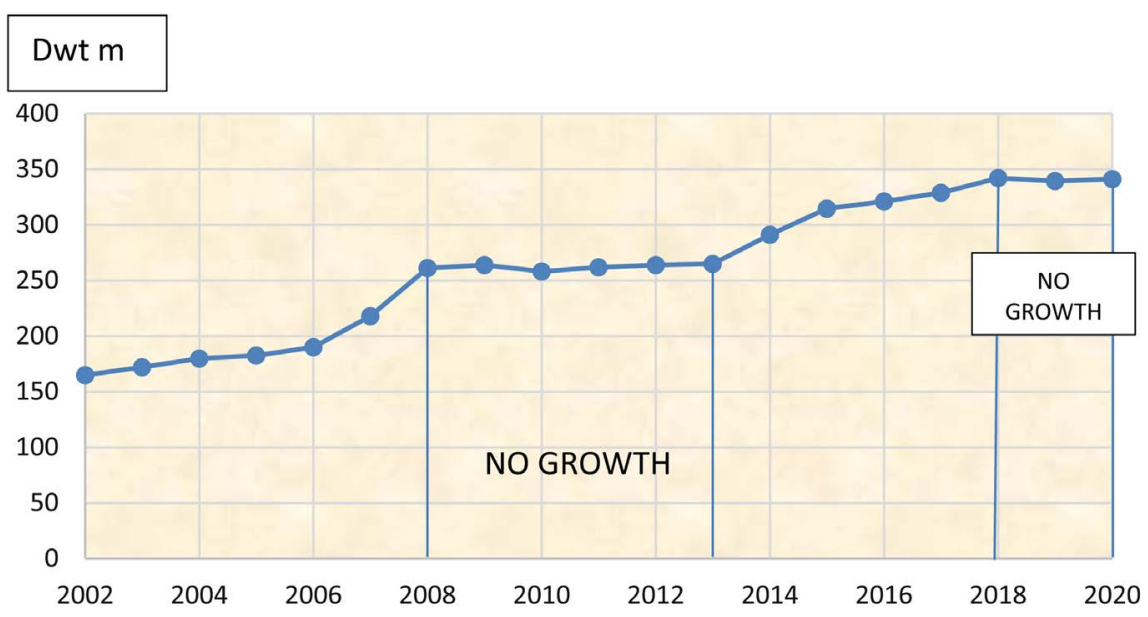

Figure 21. GOS dwt (million), 2002-2020 April. Source: data from GSCC.

${ }^{25}$ As well nuclear and military. 
price from $\$ 70 \mathrm{~m}$ to $\$ 60 \mathrm{~m}$, they rushed to buy her, considering it as a unique opportunity—rather an unfulfilled manager's past dream. In a rather short time, i.e. in a number of months, however, she (the same ship) had a price of $\$ 10 \mathrm{~m}$ ! This is why we underlined the term of brokers: "rock-bottom".

\subsection{How to Spot a Rock-Bottom Price?}

One may argue that it is difficult for a manager to recognize rock-bottom prices! A manager, however, may: 1) discuss this with an external $\mathrm{S}+\mathrm{P}$ broker. And even better: 2) he/she can discuss it with company's in-house $\mathrm{S}+\mathrm{P}$ broker, if there is one (we recommend to be). And 3) one may use historical data, as follows (Figure 22).

As shown, the price of a 25,000-dwt bulk carrier fluctuated down from her 10 -year average price: $28 \%$ in $1990-1991 ; 28 \%$ in 1992 and $31 \%$ in 1998 . So, if this ship, let say, had an average price of $\$ 30 \mathrm{~m}$, then her rock-bottom price is between: $\$ 21 \mathrm{~m}$ and $\$ 22 \mathrm{~m}$. If this price emerges in future for a similar ship, then the manager may buy her. To sell her, PT suggests 1996, at $\$ 41 \mathrm{~m}$, providing a profit of $\$ 11 \mathrm{~m}$ plus the accumulated depreciation.

\subsection{The PT Applied by GOS}

Appendix 2 proves that the average size of orders of both tankers and ore/bulk carriers, (84\% share in GOS in 2020), is higher than the average size of existing fleet, (economies of scale), from 2002 to 2020. This demonstrates that Greeks build larger ships, when they have the opportunity. Are the prices of used ships rock bottom (Figure 23) as we have argued?

As shown, the years of PT were: 1976-1979 and 1983-1987, which were, also, periods of recession/depression. Greeks bought 1568 ships in 1976-1979, and sold 1405. Allow one-year gap between buying and selling, because Greeks first buy and then sell. Sales got rid of 1550 ships! As shown, the two curves move together, but with the acquisitions to come first, and sales to be equal or

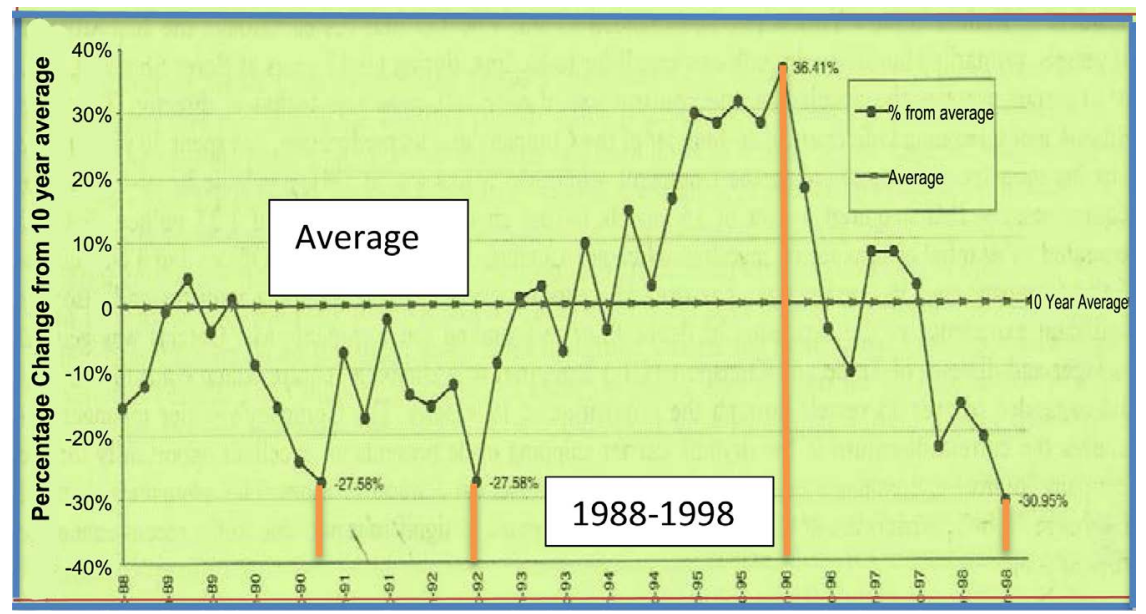

Figure 22. \% Changes in the Price of a handy dry-bulk ship 25,000 dwt, 1988-1998. Source: not recorded; modified. 


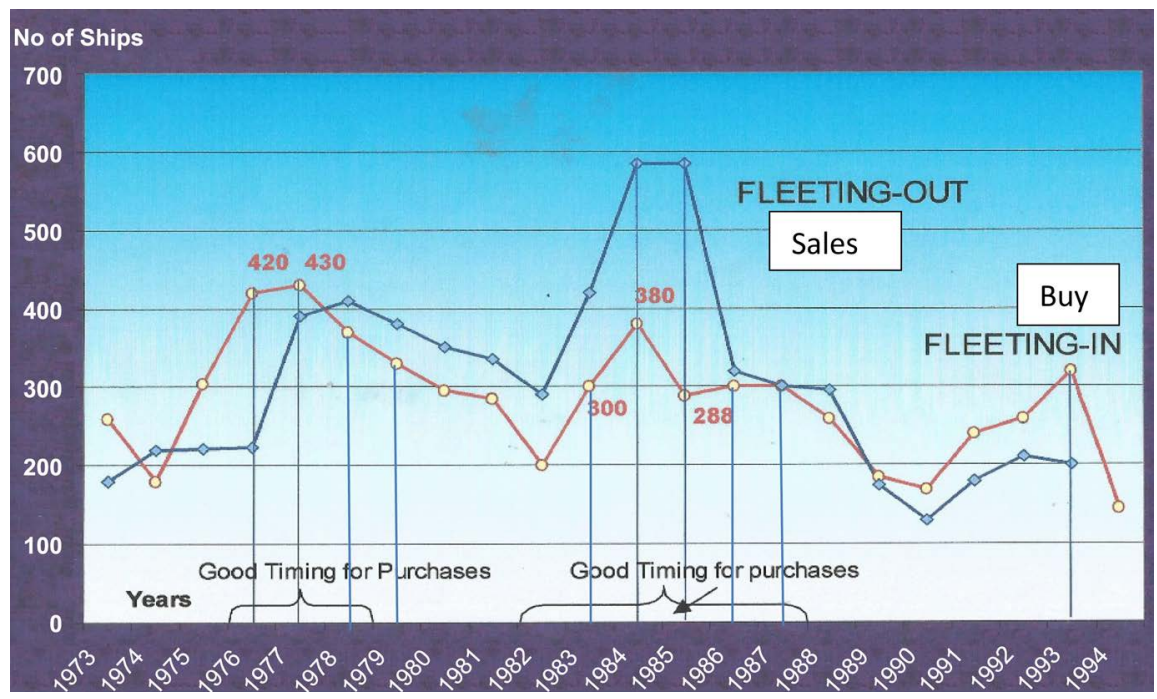

Figure 23. Greek owned fleet (No of Ships) additions to fleet \& reduction 1973-1994. Source: author.

higher in numbers (1978-1988). This is also a strategy, we believe, as when one buys at rock bottom prices stimulates the market and the ships sold subsequently may achieve a better price...

During the 1981-1987 depression, ships bought were 1568 and those sold 1910, with one-year delay: 1790. One may conclude that the ships bought are larger than those sold and for this reason are fewer...

What about their prices? (Figure 24).

As shown, in 1982-end 1987, the 4 sizes of the $2^{\text {nd }}$ hand bulk carriers had their lowest prices, i.e. below $\$ 5 \mathrm{~m}$ each, (for 2 of them), against $\sim 25$ at their peak (1980), and \$1.5m each in mid-1986 (rock-bottom). Assuming that Greeks have bought such ships, we constructed (Table 2).

As shown, GOS applied a very good, but not a perfect timing in buying 2nd hand ships as it paid substantially lower prices (i.e. minus 86.5\%) from the peak prices prevailed in 1980 for the same ships. But it paid $\$ 2.94 \mathrm{~b}$ extra. We are sure that the PT for 1983-1987 was in 1986 at a price of $\$ 1.5 \mathrm{~m}$ for Greeks to buy ships.

We will examine now if acquisitions in GRT will give the same picture as the number of ships (Figure 25).

As shown, GOS purchases in GRT peaked in 1986 with 3.6m and in 1993 with $3.8 \mathrm{~m}$. In 1984 was the year when purchases in number of ships also peaked (Figure 23). The average size of purchases varied from 8333 GRT in 1983 to 11,875 in 1993 , confirming GOS strategy $\left(12,000\right.$ GRT in 1986) to buy larger $2^{\text {nd }}$ hand ships when the opportunity comes.

What about age of GOS' fleet?

As shown in Figure 26, GOS got rid of old tonnage of oil tankers from $12 \mathrm{~m}$ GRT in 2002 to $0.04 \mathrm{~m}$ GT in 2020 ! This indicates that GOS adapted to the fact that tankers, of 15 years or above, are not preferred by charterers due to the fear of a marine accident, especially after and during the 2008-2013 depression. The same happens with non-tankers (Figure 27). 


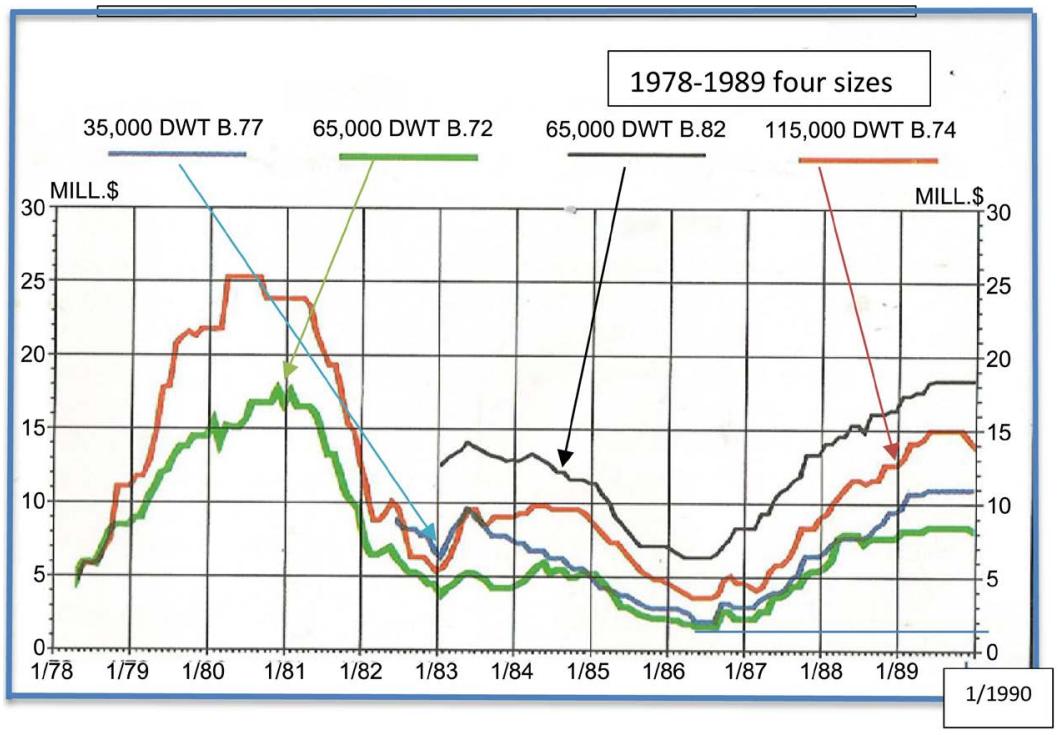

Figure 24. Market values of bulk carriers (estimated). Source: modified, from Platou A/S.

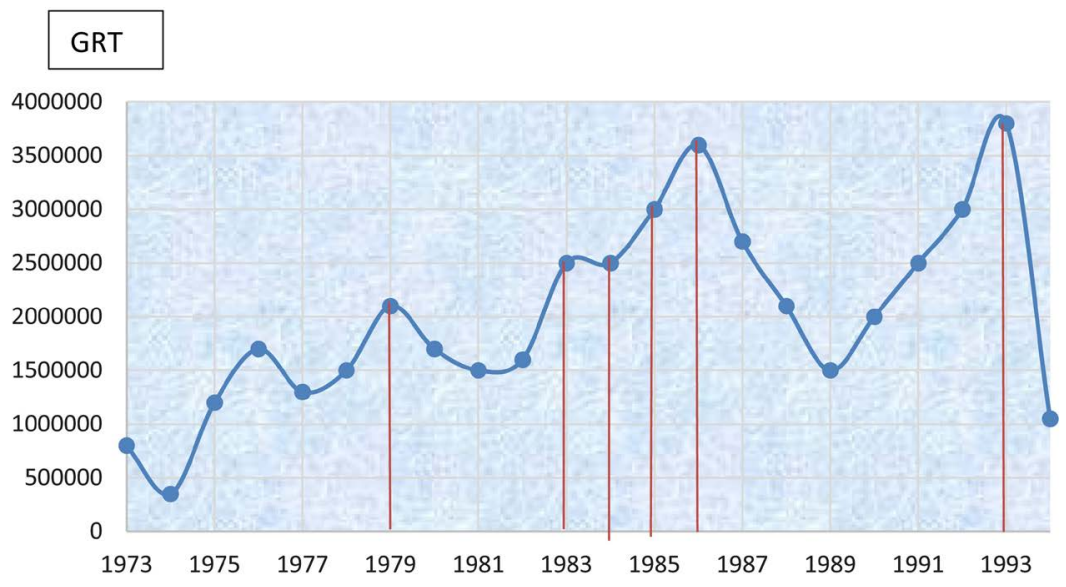

Figure 25. Purchases of GOS in GRT, 1973-1994. Source: author.

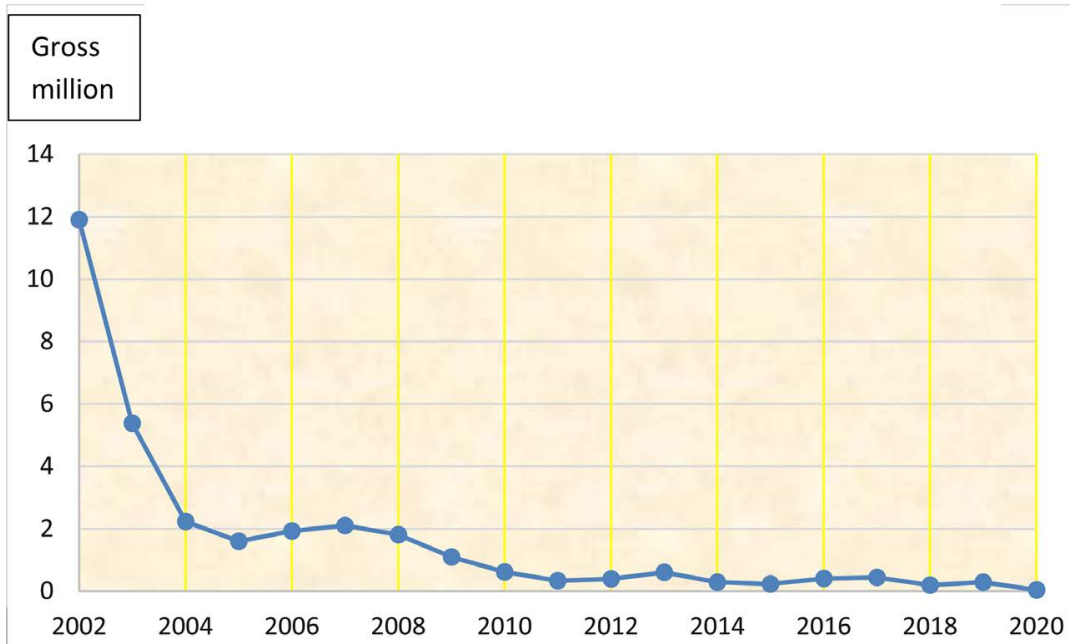

Figure 26. Oil tankers in GOS of 25 years of age and over, 2002-2020 (ships > 1000 GT). Source: data from GSCC various years. 
Table 2. GOS acquisitions, 1983-1987 (number of ships), prices, total spending and perfect timing.

\begin{tabular}{cccccc}
\hline Years & $\begin{array}{c}\text { Number of } \\
\text { ships bought }\end{array}$ & $\begin{array}{c}\text { Price prevailing } \\
\text { from Figure } 24) \\
\text { million } \$\end{array}$ & $\begin{array}{c}\text { Total pay } \\
\text { (billion \$) }\end{array}$ & PT (million \$) & $\begin{array}{c}\text { Pay at } 1980 \\
\text { price of } \$ 25 \mathrm{~m} \\
\text { total }\end{array}$ \\
\hline 1983 & 300 & $\begin{array}{c}\$ 3.14 \text { (a weighted } \\
\text { average) }\end{array}$ & $\$ 0.942$ & $\$ 450(300 \times \$ 1.5)$ & $\$ 7.5 \mathrm{~b}$ \\
$1984-1985$ & 668 & $\begin{array}{c}\$ 5 \& \$ 4 \text { from } \\
\text { Figure } 24)=\$ 4.5\end{array}$ & $\$ 3.0$ & $\$ 1000(668 \times \$ 1.5)$ & $\$ 16.7 \mathrm{~b}$ \\
1986 & 300 & $\$ 2.25$ & $\$ 0.675$ & $\$ 450$ & $\$ 7.5 \mathrm{~b}$ \\
1987 & 300 & $\$ 2.25$ & $\$ 0.675$ & $\$ 450$ & $\$ 7.5 \mathrm{~b}$ \\
total & 1568 & 3.375 & $\$ 5.292$ & $\$ 2.35$ & $\$ 39.2 \mathrm{~b}$ \\
\hline
\end{tabular}

Source: author from Figure 23 and Figure 24.

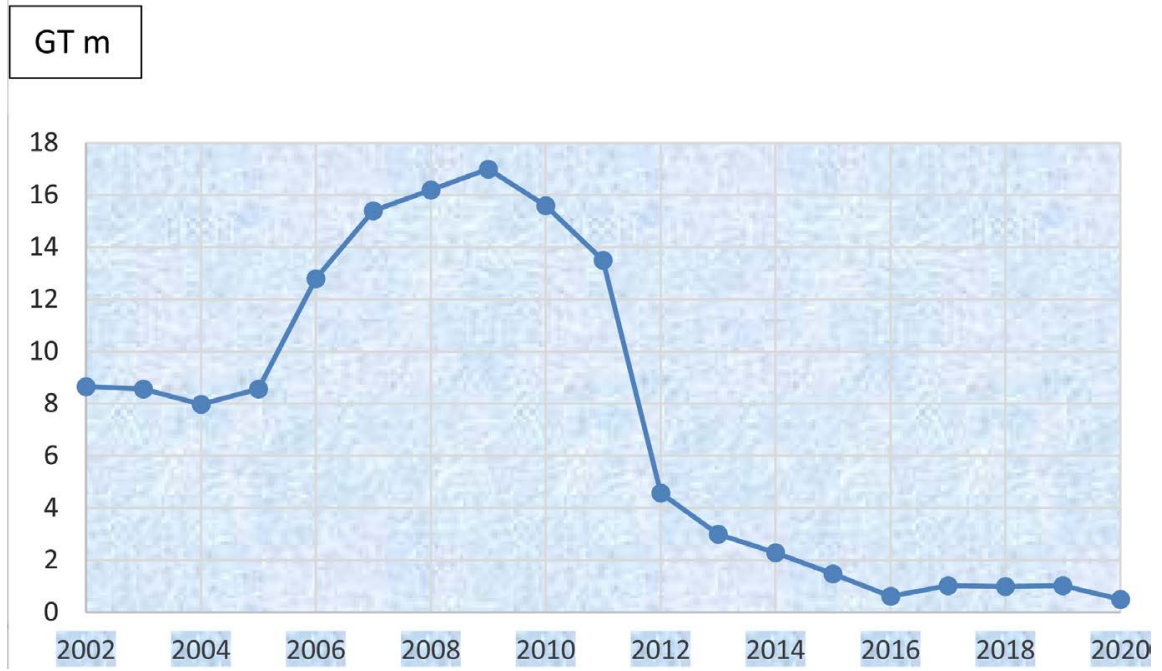

Figure 27. GOS Ore \& Bulk Carriers at 25 years and over, 2002-2020 million GT (ships > 1000 GT). Source: author; from data of GSCC.

As shown, old Ore \& bulk carriers were in favor of GOS since 2002 due to the trade with China, with a peak of $17 \mathrm{~m}$ in 2009 . Then the depression wiped-themout between 2012 and $2020(0.05 \mathrm{~m})$.

\section{Conclusion}

After years of observation of GOS growth, we came to the conclusion that GOS strategy is. 1) to "buy" and "build" ships when their prices are low and freight rates high when delivered; 2) to "build" ships larger than hitherto; 3) to "buy" ships larger and younger than those owned hitherto; 4) to "sell" afterwards ships smaller and older. This is a win-win policy providing economies through lower capital cost, economies of scale, economies of age (younger ships) by creating a competitive advantage.

We gave a great emphasis on shipping cycles and on GOS growth no doubt. The last one is necessary to appreciate the effectiveness of a strategy. We showed 
also the important role which shipbuilders have played all along by cutting down building time and providing finance, as well low prices during depressions. Shipowners order ships, no doubt, and they bear the prime responsibility for this when it becomes over.

Recessions and depressions, as well the 2 global wars, left GOS half-dead. USA contributed to GOS' recovery with 100 or so Liberties "sold/leased" in 1946.

Rates of growth of GOS fell behind 4\%, the typical rate, several times since 1945 , but negative rates emerged in only 10 years out of 76 (13\%): in 1960; during tanker crisis $(1978 ; 1982)$; during dry cargo crisis $(1984 ; 1986)$; in 1989; 1997; 2002; during banking crisis in 2010; in 2019 and 2020. Whatever GOS' strategy, we may conclude with certainty, could never beat wars, recessions or depressions. But it tried to get advantage of them... This is an escape way when forecasting is impossible. Some call it: "perfect timing strategy"... but no one is perfect and in shipping it is sufficient not to be perfect but better than the others...

The "6-days war" in 1973 collapsed tanker market-something when Onassis died in 1975 to experience it, unlike Niarchos, while dry cargo resisted till 1974, and small cargo ships till 1975. In 1975 the tanker market moved thereafter independently from dry cargo and for the next 20 years, while in the past used to move synchronized.

After 1945, and till 2020, notably only 10 shipping cycles occurred, over 76 years, reducing, (excluding the 2008-13 depression and the 2020-21-Pandemic), the average duration of cycles to 7.6 years from 19 years in 1740s! Technology brought cycles closer... But we showed that cycles are needed for a PT. The shorter cycles are due to the increased speed of ship production (automation) and the use of robots-in-welding; also, a massive and series production is carried-out (plus sister ships) nowadays and for some time. Shipbuilding ${ }^{26}$ cut production time of a vessel down to 3 months on average on a high demand, depending on type and size of vessel.

The hard facts of shipping markets are: "the impossibility to forecast" together with Cyclicality and Volatility. Whoever learned to fight these 3 is the King among shipowners...

As paper's data showed, Greeks shipowners were not perfect, but very good; they bought ships $86.5 \%$ cheaper vis-à-vis their peak past price (in 1980), younger, as well larger. They paid few billion dollars extra as they could not foretell rock-bottom prices exactly. Our PT theory may help them to become better.

\section{Conflicts of Interest}

The author declares no conflicts of interest regarding the publication of this paper.

\footnotetext{
${ }^{26}$ One may remember that Japanese allowed no reduction in industries' personnel as their employment policy was work for life. So, they had to offer low shipbuilding prices and finance to avoid sackings. At that time about 18 new Greek shipowners emerged! Japan replaced UK, and their $2^{\text {nd }}$ hand ships were bought by Greeks by dozen as approached 12 years in service and sold by Japanese in dozens.
} 


\section{References}

Dunn, L. (nd). A Feel for the Tramp Trades, 5000 Weeks of "Fairplay" (or 96 Years plus 8 Weeks), "Fairplay" Shipping Weekly.

Georgantopoulos, El. (1963). The Greek Shipping Policy and the Last Maritime Crisis. Doctoral Thesis, Athens: Graduate School of Economic and Commercial Sciences.

Goulielmos, A. M. (1974). A Vintage Model Approach to Some Problems of Shipping Economics. Unpublished Doctoral Thesis, London: Brunel University.

Goulielmos, A. M. (2017). The "Kondratieff Cycles" in Shipping Economy since 1741 and till 2016. Modern Economy, 8, 308-332. https://doi.org/10.4236/me.2017.82022

Goulielmos, A. M. (2019). Forecasting the Next Dry Cargo Shipping Depression beyond 2018. Modern Economy, 10, 1684-1712. https://doi.org/10.4236/me.2019.107110

Harlaftis, G. (1996). A History of Greek-Owned Shipping: The Making of an International Tramp Fleet, 1830 to the Present Day. London: Routledge.

Kondratieff, N. D. (1950). The Long Waves in Economic Life. Readings in Business Cycle Theory, from Review of Economic Statistics, 1935; First Published in German, 1926.

McConville, J., \& Rickaby, G. (1995). Shipping Business \& Maritime Economics: An Annotated International Bibliography. London: Mansell Publishing.

Schumpeter, J. A. (1954). History of Economic Analysis. London: Allen and Unwin.

Stopford, M. (2009). Maritime Economics (3rd ed.). London: Routledge. https://doi.org/10.4324/9780203891742

Vassiliou, S. (1961). Greek Merchant Ships, Collection of Paintings. Piraeus: Seamen Pension Fund. 


\section{Appendix 1}

Table A1. The calculation of mode of GOS' growth, 1949-2020, in GRT, GT and in DWT.

\begin{tabular}{|c|c|c|c|c|c|}
\hline Year & $\begin{array}{c}\% \text { change from year } \\
\text { before in GRT }\end{array}$ & Year & $\begin{array}{c}\% \text { change from year } \\
\text { before in GRT }\end{array}$ & Year & $\begin{array}{c}\% \text { change from year } \\
\text { before in GRT }\end{array}$ \\
\hline 1949 & - & 1973 & 9 & 1997 & -0.2 \\
\hline 1950 & 7 & 1974 & 6 & 1998 & 5 \\
\hline 1951 & 30 & 1975 & 6 & 1999 & 6 \\
\hline 1952 & 10 & 1976 & 5 & 2000 & 8.5 \\
\hline 1953 & 18 & 1977 & 5 & 2001 & 11 \\
\hline 1954 & 26 & 1978 & -1 & 2002 & $-2 \mathrm{DWT}$ \\
\hline 1955 & 16 & 1979 & 1 & 2003 & 4 \\
\hline 1956 & 26 & 1980 & 1 & 2004 & 5 \\
\hline 1957 & 26 & 1981 & 1 & 2005 & 1 \\
\hline 1958 & 15 & 1982 & -2 & 2006 & 4 \\
\hline 1959 & 7 & 1983 & 6 & 2007 & 15 \\
\hline 1960 & -1 & 1984 & -4.5 & 2008 & 20 \\
\hline 1961 & 8 & $1985\left(^{*}\right)$ & ---- & 2009 & 1 \\
\hline 1962 & 3 & 1986 & -3 & 2010 & -2 \\
\hline 1963 & 13 & 1987 & 4 & 2011 & 1.5 \\
\hline 1964 & 10 & 1988 & 1 & 2012 & 0.8 \\
\hline 1965 & 12 & 1989 & -0.5 & 2013 & 0.4 \\
\hline 1966 & 6 & 1990 & 3 & 2014 & 10 \\
\hline 1967 & 11 & 1991 & 5 & 2015 & 8 \\
\hline 1968 & 9 & 1992 & 7 & 2016 & 2 \\
\hline 1969 & 13 & 1993 & 11 & 2017 & 2.5 \\
\hline 1970 & 15 & $1994^{* *}$ & - & 2018 & 4 \\
\hline 1971 & 10 & 1995 & 8 & 2019 & -1.4 \\
\hline 1972 & 15 & 1996 & 5 & 2020 & 0.44 \\
\hline
\end{tabular}

${ }^{*}$ ) Ships over 1000 GRT from "Naftica Chronica"; (**) Ships over 1000 GT from Greek Shipping cooperation committee. GT > GRT

Table A2. The frequency distribution of GOS growth, 1949-2020.

\begin{tabular}{ccc}
\hline$\%$ growth & cases & \% rounded \\
\hline $0 \%$ and $<0 \%$ & 10 & 14 \\
$>0 \%-6 \%$ & 29 & 42 higher frequency \\
$7 \%-12 \%$ & 17 & 25 \\
$13 \%-18 \%$ & 8 & 12 \\
$19 \%-24 \%$ & 1 & 6 \\
$25 \%-30 \%$ & 4 & $100 \%$ \\
total & 69 years &
\end{tabular}

Source: Table A1. 


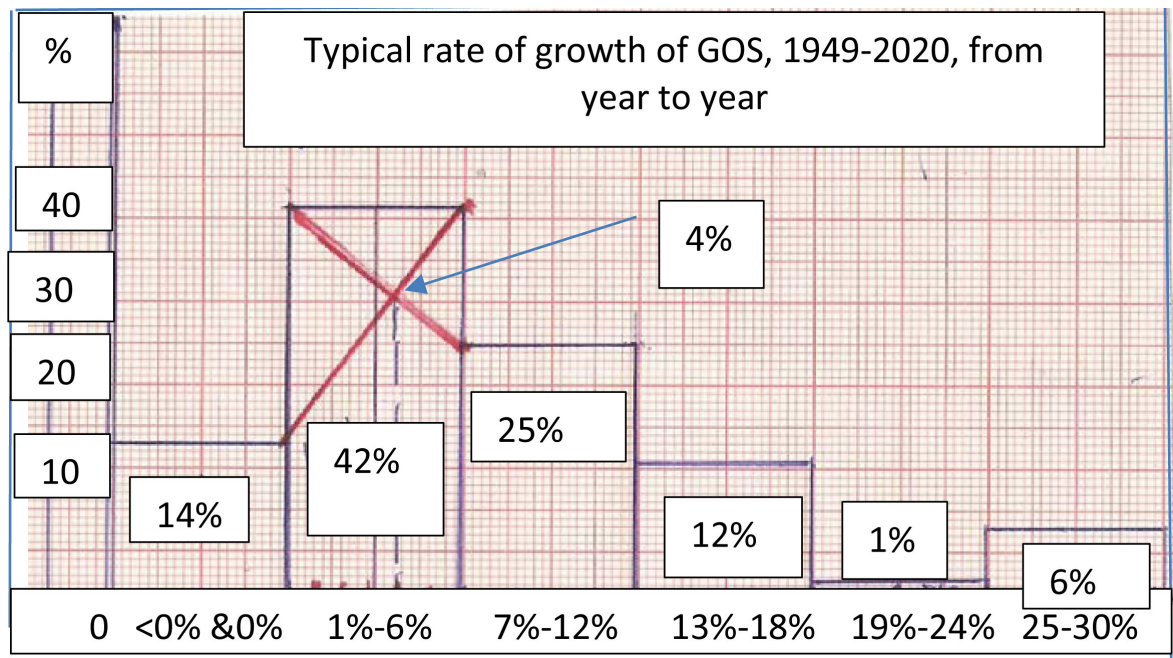

Figure A1. The frequency distribution of growth rates of GOS, 1949-2020. Source: Table A2.

As shown, $4 \%$ is the typical rate of growth.

\section{Appendix 2}

Table A3. GOS' tankers and ore \& bulk carriers existing and on order (number \& dwt) and their average size plus fleet's total, 2002-2020.

\begin{tabular}{|c|c|c|c|c|c|c|c|c|c|c|c|c|c|}
\hline Year & $\begin{array}{c}\text { Tankers in } \\
\text { the fleet }\end{array}$ & DWT m & $\begin{array}{l}\text { Av. Size } \\
(000)\end{array}$ & $\begin{array}{l}\text { Tankers } \\
\text { On order }\end{array}$ & $\begin{array}{c}\text { DWT } \\
\text { m }\end{array}$ & $\begin{array}{c}\text { Size (av.) } \\
(000)\end{array}$ & $\begin{array}{l}\text { Ore \& Bulk } \\
\text { in the fleet }\end{array}$ & $\begin{array}{c}\text { Dwt } \\
\mathrm{m}\end{array}$ & $\begin{array}{c}\text { Dwt Av. } \\
(000)\end{array}$ & $\begin{array}{l}\text { On } \\
\text { order }\end{array}$ & $\begin{array}{c}\text { Dwt } \\
\mathrm{m}\end{array}$ & $\begin{array}{l}\text { Size } \\
\text { Av. }\end{array}$ & $\begin{array}{c}\text { GOS } \\
\mathrm{m}\end{array}$ \\
\hline 2002 & 446 & 54 & 122 & 57 & 10 & 174 & 1357 & 72 & 53 & 61 & 4 & 68 & 165 \\
\hline 2003 & 511 & 66 & 129 & 64 & 9.5 & 148 & 1313 & 76 & 58 & 48 & 5 & 108 & 172 \\
\hline 2004 & 493 & 66 & 135 & 81 & 12 & 153 & 1345 & 81 & 60 & 53 & 5 & 88 & 180 \\
\hline 2005 & 502 & 67 & 133 & 78 & 12 & 156 & 1384 & 85 & 61 & 86 & 8 & 95 & 182 \\
\hline 2006 & 536 & 70 & 130 & 62 & 10 & 162 & 1397 & 87 & 62 & 92 & 9 & 102 & 190 \\
\hline 2007 & 595 & 83 & 139 & 120 & 21 & 173 & 1469 & 97 & 66 & 164 & 16 & 95 & 218 \\
\hline 2008 & 592 & 84 & 142 & 125 & 21 & 166 & 1793 & 131 & 73 & 487 & 49 & 100 & 261 \\
\hline 2009 & 600 & 87 & 145 & 165 & 22 & 167 & 1802 & 132 & 73 & 547 & 52 & 96 & 264 \\
\hline 2010 & 608 & 88 & 145 & 111 & 20 & 178 & 1722 & 127 & 74 & 442 & 40 & 91 & 258 \\
\hline 2011 & 595 & 93 & 157 & 103 & 20 & 191 & 1747 & 128 & 73 & 381 & 31 & 82 & 262 \\
\hline 2012 & 598 & 94 & 157 & 68 & 14 & 206 & 1678 & 126 & 75 & 234 & 20 & 84 & 264 \\
\hline 2013 & 591 & 92 & 155 & 28 & 6 & 201 & 1636 & 69 & 42 & 126 & 6 & 53 & 265 \\
\hline 2014 & 632 & 100 & 158 & 44 & 7.5 & 169 & 1752 & 139 & 79 & 148 & 15 & 101 & 291 \\
\hline 2015 & 709 & 114 & 160 & 80 & 15 & 186 & 1856 & 148 & 80 & 148 & 15 & 100 & 314 \\
\hline 2016 & 717 & 115 & 161 & 106 & 18 & 172 & 1844 & 149 & 81 & 112 & 11 & 95 & 321 \\
\hline 2017 & 738 & 119 & 161 & 75 & 12 & 161 & 1869 & 156 & 83 & 49 & 5 & 95 & 329 \\
\hline 2018 & 801 & 130 & 163 & 74 & 15 & 198 & 1894 & 158 & 84 & 57 & 6 & 100 & 342 \\
\hline 2019 & 798 & 130 & 162 & 36 & 8 & 216 & 1859 & 158 & 85 & 49 & 4 & 85 & 339 \\
\hline 2020 & 808 & 135 & 167 & 61 & 10 & 171 & 1788 & 152 & 85 & 27 & 2 & 90 & 341 \\
\hline
\end{tabular}

Source: Greek Shipping Cooperation Committee. The tankers and ore \& bulk carriers selected only, as these two types occupied in $202084 \%$. 